\title{
Amyloid- $\beta$ Peptide Nitrotyrosination Stabilizes Oligomers and Enhances NMDAR-Mediated Toxicity
}

\author{
DBiuse Guivernau, ${ }^{1}$ 이 Jaume Bonet, ${ }^{2}$ Victòria Valls-Comamala, ${ }^{1}$ Mònica Bosch-Morató, ${ }^{1}$ Juan A. Godoy, ${ }^{3}$ \\ Nibaldo C. Inestrosa, ${ }^{3,4}$-Alex Perálvarez-Marín, ${ }^{5}$ Xavier Fernández-Busquets, ${ }^{6}{ }^{-D a v i d}$ Andreu, ${ }^{7}$ Baldomero Oliva, ${ }^{2}$ \\ and $\odot$ Francisco J. Muñoz ${ }^{1}$ \\ ${ }^{1}$ Laboratory of Molecular Physiology, Experimental and Health Sciences, Universitat Pompeu Fabra, 08003 Barcelona, Spain, ${ }^{2}$ Laboratory of Structural \\ Bioinformatics, Experimental and Health Sciences, Universitat Pompeu Fabra, 08003 Barcelona, Spain, ${ }^{3}$ Center on Aging and Regeneration, Departamento \\ de Biología Celular y Molecular, P. Universidad Católica de Chile, 8320000 Chile, ${ }^{4}$ Centre for Healthy Brain Ageing, School of Psychiatry, University of New \\ South Wales, NSW 2031 Sydney, Australia, ${ }^{5}$ Unitat de Biofísica, Departament de Bioquímica i de Biologia Molecular, Facultat de Medicina, and Centre \\ d'Estudis en Biofísica, Universitat Autònoma de Barcelona, 08193 Bellaterra, Spain, ${ }^{6}$ Nanomalaria Joint Group, Institute for Bioengineering of Catalonia \\ and Barcelona Institute for Global Health, 08036 Barcelona, Spain, and ${ }^{7}$ Laboratory of Proteomics and Protein Chemistry, Experimental and Health \\ Sciences, Universitat Pompeu Fabra, 08003 Barcelona, Spain
}

Alzheimer's disease $(\mathrm{AD})$ is a neurodegenerative disorder characterized by the pathological aggregation of the amyloid- $\beta$ peptide $(\mathrm{A} \beta)$. Monomeric soluble $\mathrm{A} \beta$ can switch from helicoidal to $\beta$-sheet conformation, promoting its assembly into oligomers and subsequently to amyloid fibrils. Oligomers are highly toxic to neurons and have been reported to induce synaptic transmission impairments. The progression from oligomers to fibrils forming senile plaques is currently considered a protective mechanism to avoid the presence of the highly toxic oligomers. Protein nitration is a frequent post-translational modification under AD nitrative stress conditions. $\mathrm{A} \beta$ can be nitrated at tyrosine 10 (Y10) by peroxynitrite. Based on our analysis of ThT binding, Western blot and electron and atomic force microscopy, we report that $\mathrm{A} \beta$ nitration stabilizes soluble, highly toxic oligomers and impairs the formation of fibrils. We propose a mechanism by which fibril elongation is interrupted upon Y10 nitration: Nitration disrupts fibril-forming folds by preventing H14mediated bridging, as shown with an $A \beta$ analog containing a single residue $(\mathrm{H}$ to $\mathrm{E})$ replacement that mimics the behavior of nitrated $\mathrm{A} \beta$ related to fibril formation and neuronal toxicity. The pathophysiological role of our findings in AD was highlighted by the study of these nitrated oligomers on mouse hippocampal neurons, where an increased NMDAR-dependent toxicity of nitrated A $\beta$ oligomers was observed. Our results show that $\mathrm{A} \beta$ nitrotyrosination is a post-translational modification that increases $\mathrm{A} \beta$ synaptotoxicity.

Key words: Alzheimer; amyloid; nitrotyrosination; NMDA Rc; oligomers; peroxynitrite

\section{Significance Statement}

We report that nitration (i.e., the irreversible addition of a nitro group) of the Alzheimer-related peptide amyloid- $\beta$ (A $\beta$ ) favors the stabilization of highly toxic oligomers and inhibits the formation of $A \beta$ fibrils. The nitrated $A \beta$ oligomers are more toxic to neurons due to increased cytosolic calcium levels throughout their action on NMDA receptors. Sustained elevated calcium levels trigger excitotoxicity, a characteristic event in Alzheimer's disease.

\section{Introduction}

Alzheimer's disease $(\mathrm{AD})$ is a neurodegenerative disorder that leads to severe memory deficits, progressive cognitive decline,

Received April 1, 2016; revised Aug. 10, 2016; accepted Sept. 10, 2016.

Author contributions: B.G., J.B., V.V.-C., N.C.I., A.P.-M., X.F.-B., D.A., B.O., and F.J.M. designed research; B.G., J.B., V.V.-C., M.B.-M., J.A.G., A.P.-M., X.F.-B., and B.O. performed research; D.A. contributed unpublished reagents/ analytic tools; B.G., J.B., and B.O. analyzed data; B.G. and F.J.M. wrote the paper.

This work was supported by Spanish Plan Estatal de I+D + I 2013-2016 and the ISCIII-Subdirección General de Evaluación y Fomento de la Investigación Grants PI13/00408 and Red HERACLES RD12/0042/0014 and FEDER Funds, Spanish Ministerio de Economía y Competitividad BI02014-57518-R, BI02014-52872-R, and AGL2014-52395-C22-R and FEDER Funds, the Generalitat de Catalunya (Spain) 2014-SGR-938, and Chilean Funds for Science CONICYTPFB 12/2007 and FONDECYT N ${ }^{\circ} 1160724$. A.P.-M. was the recipient of the Universitat Autònoma de Barcelona- and neuronal death. Its pathophysiology involves oxidative and nitrative stress (Miranda et al., 2000) and the deposition of protein aggregates, that is, amyloid- $\beta(\mathrm{A} \beta)$ peptide in extracellular oligomers and senile plaques and tau in the intraneuronal neurofibrillary tangles (Masters et al., 1985; Grundke-Iqbal et al., 1986).

Programa Banco de Santander Fellowship. We thank Salvador Bartolomé for generous access to the FTIR spectrometer; and Judit Fuentes for skillful DLS data acquisition.

The authors declare no competing financial interests.

Correspondence should be addressed to Dr. Francisco J. Muñoz, Universitat Pompeu Fabra, Parc de Recerca Biomèdica de Barcelona, Carrer Doctor Aiguader 88, 08003 Barcelona, Spain. E-mail: paco.munoz@upf.edu. DOl:10.1523/JNEUROSCI.1081-16.2016

Copyright $\odot 2016$ the authors $\quad 0270-6474 / 16 / 3611693-11 \$ 15.00 / 0$ 
For $>20$ years, studies have pointed to $\mathrm{A} \beta$ accumulation as the primary event in $\mathrm{AD}$ pathogenesis. This constitutes the basis of the amyloid cascade hypothesis. $\mathrm{A} \beta$ is the product of the sequential cleavage of amyloid precursor protein (APP) by $\beta$-site APP cleaving enzyme 1 (BACE-1) (Vassar et al., 1999) and $\gamma$-secretase (Xia et al., 1998). It is widely accepted that an imbalance between $\mathrm{A} \beta$ production and clearance causes the pathogenic events that lead to AD (Hardy and Selkoe, 2002).

Soluble $A \beta$ is able to aggregate in $\beta$-sheets forming primary structures called oligomers; these can assemble to form protofibrils as intermediate structures between aggregates and mature fibrils (Arimon et al., 2005). However, density of senile plaques does not correlate with cognitive deficits, and alterations in synaptic transmission take place before neuronal death (Murrell et al., 1991; Hsia et al., 1999). It has been proposed that $A \beta$ effects on synaptic transmission are due to soluble forms of $\mathrm{A} \beta$ rather than mature fibrils (Selkoe, 2002). Oligomers have been shown to be the most neurotoxic form of $A \beta$ and to impair synaptic plasticity (Klein, 2002; Selkoe, 2008).

The hippocampus, with its high density of glutamatergic neurons and NMDARs, has a crucial role in memory and learning. It is also one of the first and most severely affected structures in AD. Consistent with the involvement of NMDARs in memory and learning, alterations in the glutamatergic transmission by $A \beta$ have been linked to the pathophysiological mechanisms underlying AD (Danysz and Parsons, 2012).

Chronic activation of NMDARs, which translates into higher cytoplasmic calcium $\left(\mathrm{Ca}^{2+}\right)$ levels, leads to cell death and neurodegeneration through the process known as excitotoxicity (Esposito et al., 2013). In addition, elevated calcium levels trigger the activation of neuronal nitric oxide (NO) synthase (nNOS) through $\mathrm{Ca}^{2+}$-calmodulin, producing NO (Dawson and Dawson, 1996).

$\mathrm{A} \beta$ can increase the production of $\mathrm{NO}$ by promoting the activation of neuronal and inducible NOS (Meda et al., 1995; Rossi and Bianchini, 1996). NO reacts with the superoxide $\left(\mathrm{O}_{2}^{--}\right)$produced by the mitochondria and other free radical sources forming peroxynitrite anion $\left(\mathrm{ONOO}^{-}\right)$, which nitrates proteins (Beckman and Koppenol, 1996). Protein nitration is an irreversible, post-translational modification that adds a nitro group to an amino acid, but mainly to a tyrosine, giving 3-nitrotyrosine residues (Guix et al., 2005); increased levels of protein nitration exist in AD (Smith et al., 1997). Numerous proteins have been reported to be affected by amyloid-dependent nitrotyrosination, thus severely affecting their function: presenilins (Guix et al., 2012), albumin (Ramos-Fernández et al., 2014), and the glycolytic enzymes triosephosphate isomerase (Guix et al., 2009; IllRaga et al., 2010; Tajes et al., 2013, 2014), $\alpha$-enolase (Castegna et
B

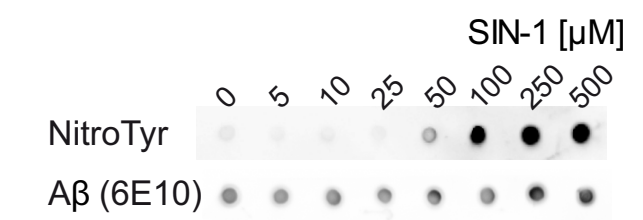

C

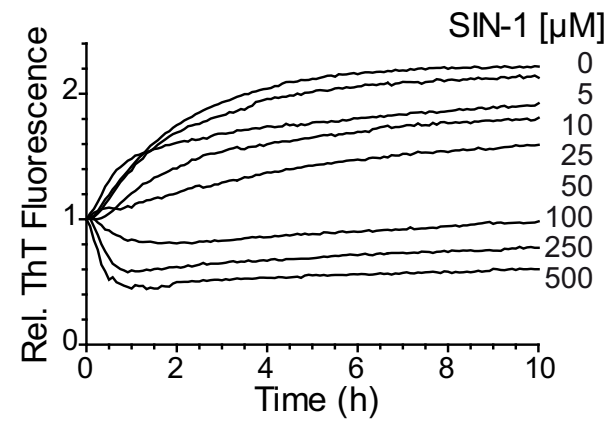

D

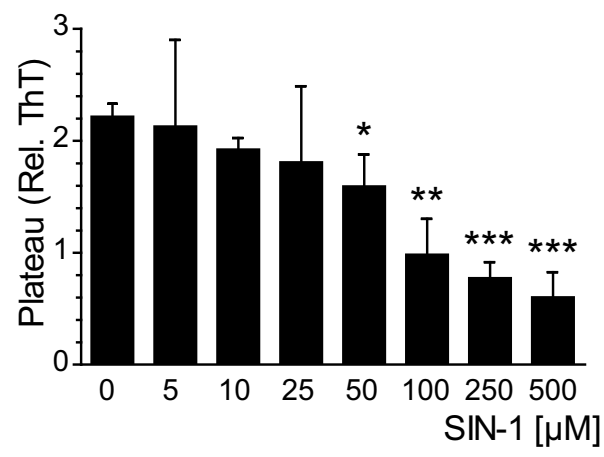

Figure 1. $A \beta$ nitrotyrosination impairs fibril formation. $A$, Presence of nitrotyrosinated $A \beta$ within amyloid plaques of the hippocampus from an $A D$ patient. Colocalized pixels appear in white. $\boldsymbol{B}$, Dot blot of synthetic $A \beta_{42}$ treated with increasing concentrations of SIN-1 probed with an anti-nitrotyrosine and $6 \mathrm{E} 10$ anti-A $\beta$ antibodies. $\boldsymbol{C}$, ThT aggregation assay with synthetic independent experiments. $\boldsymbol{D}$, Plateau phase ThT values of the data shown in $\boldsymbol{C}$. Mean \pm SEM of $3-6$ independent experiments. ${ }^{*} p<0.05$ (Student's $t$ test). ${ }^{* *} p<0.01$ (Student's $t$ test). ${ }^{* * *} p<0.001$ (Student's $t$ test).

al., 2003), and glutamate dehydrogenase (Reed et al., 2009), among others.

$\mathrm{A} \beta$ has one tyrosine (Y10) in its sequence, which is surrounded by negatively charged amino acids, making protein nitration very likely (Guix et al., 2005). Accordingly, Kummer et al. (2011) reported increased levels of nitrotyrosinated $\mathrm{A} \beta$ and its presence in the core of amyloid plaques in $\mathrm{AD}$ brains. Study of the mechanisms underlying $A \beta$ aggregation and the modulating factors is critical to the development of new therapeutic strategies targeting $\mathrm{A} \beta$. We report the effect of $\mathrm{A} \beta$ nitrotyrosination in oligomer stability, fibrillation impairment, and increased excitotoxicity, and we propose and validate a bioinformatic model regarding the progression to fibrils of nitrated $\mathrm{A} \beta$.

\section{Materials and Methods}

Immunofluorescence detection of nitrated amyloid in human hippocampal samples. The $20 \mu \mathrm{m}$ PFA-fixed and mounted slices of hippocampal human samples from an $\mathrm{AD}$ patient were supplied by the Banc de Teixits Neurològics (Neurological Tissue Bank of the Biobank-Hospital ClínicIDIBAPS, Barcelona, Spain). Handling and investigation with the human 
A

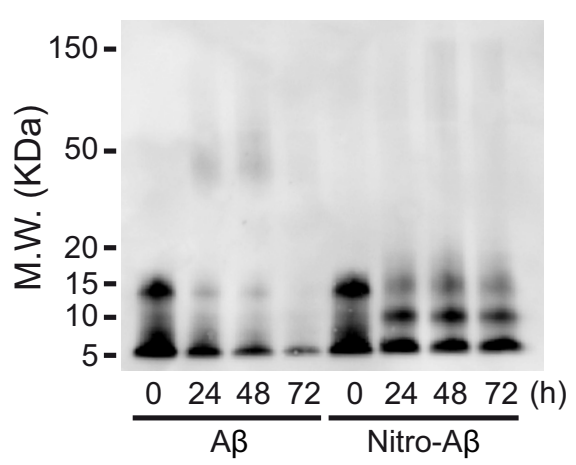

C
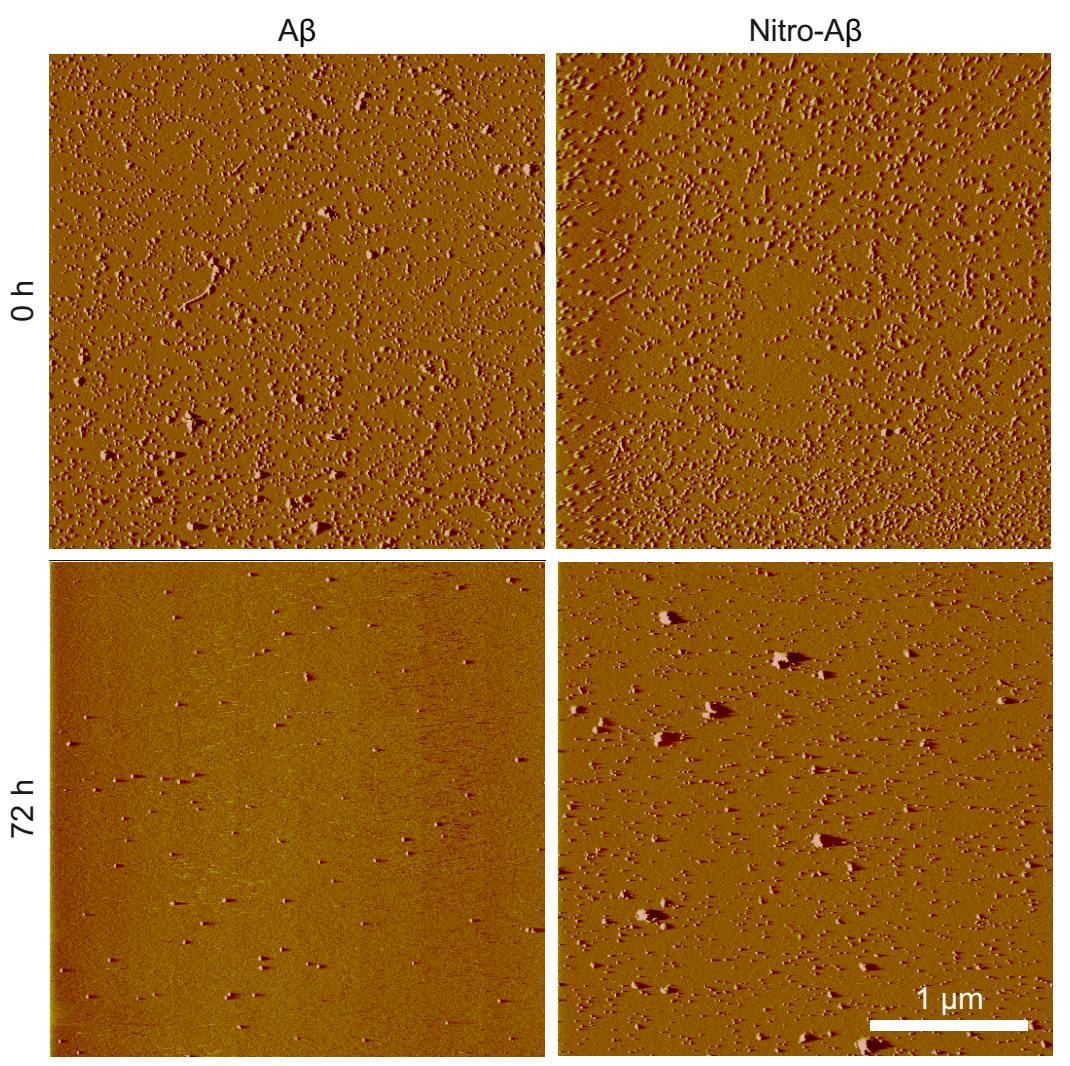

Figure 2. $A \beta$ nitrotyrosination stabilizes low molecular weight oligomers. $A$, Representative Western blot of $A \beta_{42}$ control and $A \beta_{42}$ treated with $100 \mu \mathrm{M}$ SIN-1 (nitro-A $\beta$ ) at different times of aggregation probed with $6 \mathrm{E} 10$ anti-A $\beta$ antibody. $B$, Relative amounts of oligomeric species obtained by Western blot. Mean of three independent experiments. $C$, Oligomer visualization using AFM of $A \beta_{42}$ and nitro- $A \beta$ at 0 and $72 \mathrm{~h}$ of aggregation on a mica surface.

samples have been performed according to the ethical standards, to the Declaration of Helsinki, and to the Ethics Committee of the Institut Municipal d'Investigacions Mèdiques-Universitat Pompeu Fabra (ECIMIM-UPF). Slices were treated with freshly prepared $0.15 \mathrm{M}$ glycine, 10 $\mathrm{mg} / \mathrm{ml} \mathrm{NaBH}_{4}$ for $30 \mathrm{~min}$ to reduce autofluorescence. Slices were immunostained with 1:500 polyclonal rabbit anti-nitrotyrosine (Cell Signaling Technology) and 1:1200 6E10 mouse monoclonal anti-A $\beta$ (Covance) antibodies overnight at $4^{\circ} \mathrm{C}$ followed by 1:1000 Alexa-488-bound antirabbit and 1:1000 Alexa-555-bound anti-mouse as secondary antibodies (Dako) at room temperature (RT) for $1 \mathrm{~h}$. Further reduction of autofluorescence was accomplished by a $10 \mathrm{~min}$ treatment of $0.3 \%$ Sudan black in ethanol. Samples were visualized using a Leica SPE confocal microscope.

A $\beta$ peptide preparation. $\mathrm{A} \beta_{42}$ WT (Anaspec) and mutants (Peptide Synthesis Facility, UPF) were solubilized as previously described (Bitan and Teplow, 2005). For the experiments to study the aggregation and structural analysis by atomic force microscopy (AFM), lyophilized $\mathrm{A} \beta_{42}$ was solubilized with $1 \mathrm{ml}$ of $2 \mathrm{~mm} \mathrm{NaOH}$ at 1 $\mathrm{mg} / \mathrm{ml}, \mathrm{pH} \geq 10.5$. The solution was then placed in a bath-type sonicator (Diagenode) for $1 \mathrm{~min}$ at medium intensity. The $25 \mu \mathrm{g}$ aliquots were freeze-dried and stored at $-20^{\circ} \mathrm{C}$ until used. When needed, aliquots were resuspended in MilliQ water immediately before thioflavin T (ThT; Sigma-Aldrich) experiments or PBS, $\mathrm{pH} 7.4$, for the structural studies by AFM. For the experiments with cells and structural studies with the other techniques used in this work, $1 \mathrm{mg}$ of the different $\mathrm{A} \beta$ was dissolved in $250 \mu \mathrm{l}$ of MilliQ water and $\mathrm{pH}$ was adjusted to $\geq 10.5$ with $1 \mathrm{M} \mathrm{NaOH}$, to avoid the isoelectric point of $\mathrm{A} \beta$, at which aggregation propensity is maximal and solubilization is minimal. The $250 \mu \mathrm{l}$ of $20 \mathrm{~mm}$ phosphate buffer, $\mathrm{pH}$ 7.4, were added and the tubes were placed for $1 \mathrm{~min}$ in a bath-type sonicator (Bioruptor, Diagenode). Preparations were aliquoted and immediately used for subsequent experiments diluted in DMEM/F12 medium (Invitrogen ).

Oligomer preparation. The different $\mathrm{A} \beta$ were dissolved to $0.4 \mathrm{mg} / \mathrm{ml}$ in PBS (aggregation studies) or DMEM/F12 (cell and structural studies) and kept at $4^{\circ} \mathrm{C}$ at different times (from 0 to $72 \mathrm{~h}$ ). For in vitro $\mathrm{A} \beta$ nitration, the peroxynitrite donor 3-morpholinosydnonimine hydrochloride (SIN-1; Sigma-Aldrich) was weighted, freshly dissolved in PBS, and immediately added to the $\mathrm{A} \beta$ preparation.

Study of $A \beta$ nitrotyrosination by dot blot. $\mathrm{A} \beta$ peptides $(0.125 \mu \mathrm{g} / \mu \mathrm{l})$ were incubated with or without the peroxynitrite donor SIN-1 in Nunc 96-well flat-bottom, black polystyrene microplates (Thermo Scientific) for $20 \mathrm{~h}$ (unless indicated otherwise) at RT; $2 \mu$ ldrops of sample were spotted onto nitrocellulose membranes (Invitrogen) and left to dry at RT. Membranes were blocked with 5\% BSA in $0.05 \%$ Tween TBS $1 \mathrm{~h}$ at RT and incubated with 1:1000 mouse monoclonal anti-nitrotyrosine (Millipore) and 1:1000 6E10 anti-A $\beta$ antibodies in BSA/Tween TBS for 30 $\min$ at RT; 1:2500 HRP-linked goat antimouse secondary antibody (GE Healthcare) was applied for $30 \mathrm{~min}$ at RT, and then membranes were developed with ECL Substrate (Thermo Scientific) in the ChemiDoc MP imaging system.

ThT binding assay. The $1 \mathrm{~mm}$ stock ThT solution was prepared dissolving the dye in PBS. The solution was then filtered through a 0.22 $\mu \mathrm{m}$ syringe filter. ThT solution was stored at $-20^{\circ} \mathrm{C}$ in the dark. $\mathrm{A} \beta$ peptides $(0.125 \mu \mathrm{g} / \mu \mathrm{l})$ were incubated with or without the peroxynitrite donor SIN-1 and $10 \mu \mathrm{M}$ ThT in Nunc 96-well flat-bottom, black polystyrene microplates (Thermo Scientific) for $20 \mathrm{~h}$ (unless indicated otherwise) at RT. ThT fluorescence was measured every 5 min using excitation and emission wavelengths of 430 and $470 \mathrm{~nm}$, respectively, using a multiplate-reader fluorometer (FLUOstar optima, BMG Labtech).

Oligomer identification by Western blot. $\mathrm{A} \beta_{42}$ samples incubated in the presence or absence of SIN-1 were set in aggregating conditions along $72 \mathrm{~h}$. Samples were taken at different time points and resolved in Nu-PAGE $4 \%-12 \%$ Bis-Tris Protein Gels (Invitrogen) with 2-(Nmorpholino)ethanesulfonic acid running buffer. Gels were transferred to PVDF (Immobilon-P, Millipore) using a dry blotting system (Invitrogen) and boiled in PBS for 5 min. After blocking the membranes with 5\% nonfat milk $0.05 \%$ Tween PBS, they were incubated overnight with 
A
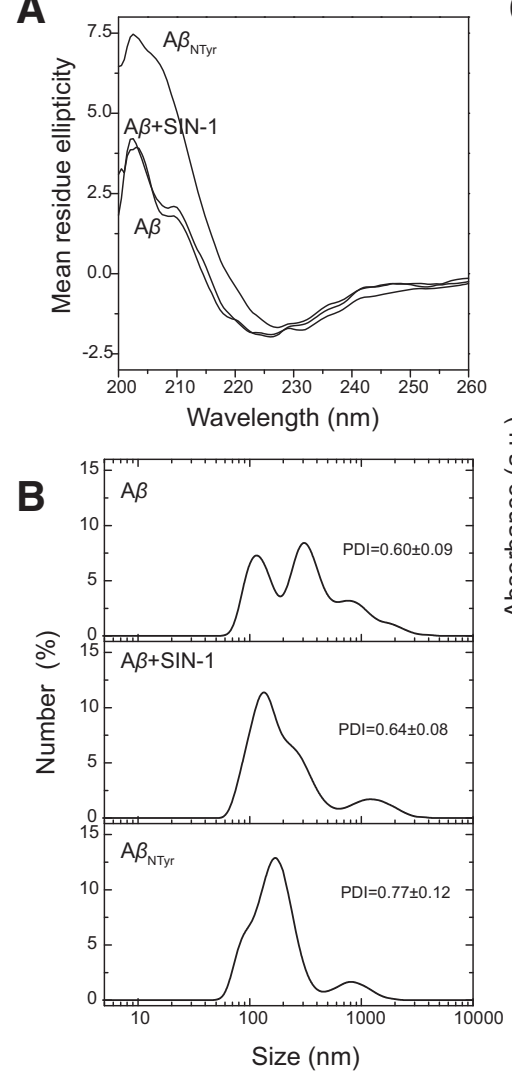

C

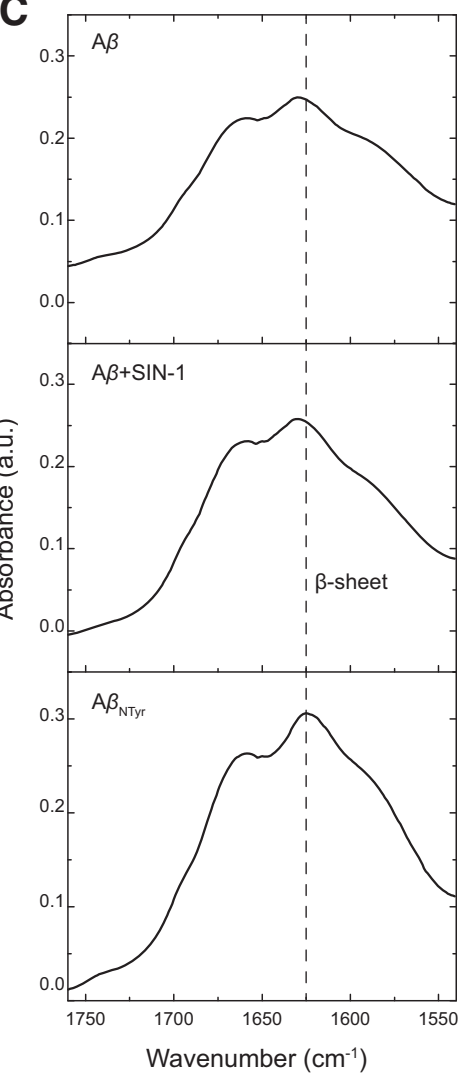

D

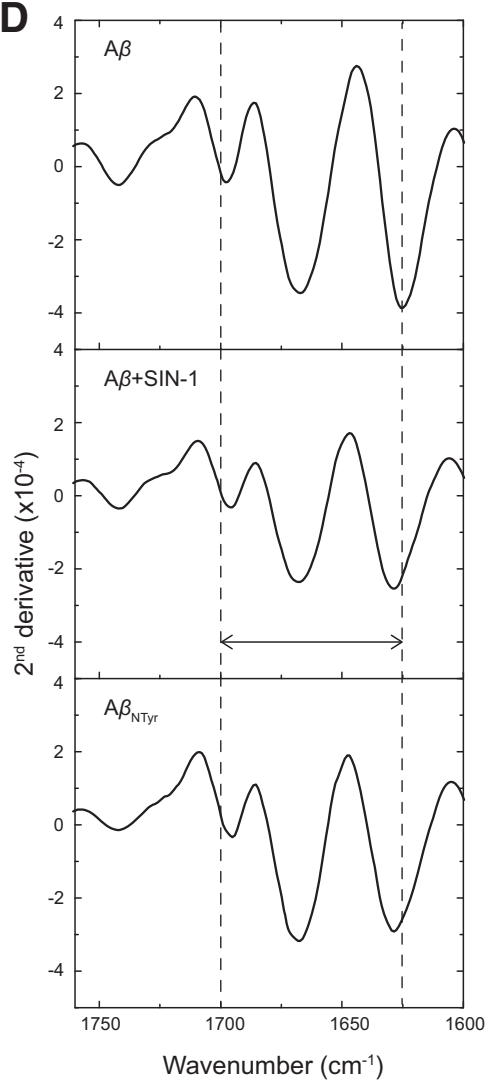

Figure 3. $A \beta$ nitrotyrosination generates low molecular weight oligomers with $\beta$-sheet structure. $A$, DLS. Size distribution measured by DLS as a function of number of particles. All the A $\beta$ oligomers tested show a high and very similar polydispersity index ( $>0.6)$. $B, C D$ spectroscopy. CD measurements of $A \beta_{42}$ and nitrotyrosinated samples showing a minimum at $\sim 225 \mathrm{~nm}$ and a maximum at $\sim 200 \mathrm{~nm}$, indicative of $\beta$-sheet structure. C, ATR-FTIR spectroscopy of the amide I region for different $\mathrm{A} \beta_{42}$ oligomers in a thin hydrated film. All spectra show the characteristic $\beta$-sheet secondary structure peak at $\sim 1630 \mathrm{~cm}$, following the band assignments of Byler and Susi (1986). D, Second derivative of the ATR-FTIR is used here to illustrate better the different secondary structures due to band narrowing (Wahlstrom et al., 2008).

1:1000 $6 \mathrm{E} 10$ anti-A $\beta$ antibody at $4^{\circ} \mathrm{C}$. The 1:2500 HRP-linked goat antimouse secondary antibody (GE Healthcare) was used at RT for $1 \mathrm{~h}$, and membranes were developed using the ECL Substrate in the ChemiDoc MP imaging system (Bio-Rad).

Structural study by AFM. A $\beta_{42}$ samples incubated in the presence or absence of SIN-1 were prepared as indicated above. Sample aliquots were frozen at different incubation times $(0,3$, and $72 \mathrm{~h})$. They were thawed at RT just before the AFM experiments. A multimode atomic force microscope (Veeco Instruments) equipped with a $12 \mu \mathrm{m}$ scanner (E-scanner) was used. The images were taken in liquid in a cell without the O-ring seal, and 5-10 $\mu \mathrm{l}$ of sample was deposited on cleaved mica substrates. After an adsorption time of $5 \mathrm{~min}, 40 \mu \mathrm{l}$ of double deionized water was added to form a drop suitable for the imaging procedure. The system was left for equilibration for at least $10 \mathrm{~min}$ before performing the experiments. NP-S (Veeco) probes were used to scan the samples in tapping mode at $0.5 \mathrm{~Hz}$ scan rate. Height and amplitude images were recorded simultaneously, although only the latter are presented in this paper.

Structural study by circular dichroism (CD) spectroscopy. A $\beta_{42}$ samples (wt, nitrated with SIN-1 and synthetically nitrated at Tyr10) were prepared as indicated above and kept for $24 \mathrm{~h}$ at $4^{\circ} \mathrm{C}$. The spectral region was recorded from 200 to $260 \mathrm{~nm}$, with a $0.5 \mathrm{~nm}$ step resolution, on a Jasco J-815 CD spectropolarimeter (Jasco) at RT using quartz cells of $1 \mathrm{~mm}$ optical path length. The scanning speed was $100 \mathrm{~nm} / \mathrm{min}$, and the spectra were collected and averaged over 6 scans. The DMEM/FC12 medium as background signal was subtracted from the CD spectra of the peptides.

Particle size distribution by dynamic light scattering (DLS). A $\beta_{42}$ samples (wt, nitrated with SIN-1 and synthetically nitrated at Tyr10) were prepared as indicated above and kept for $24 \mathrm{~h}$ at $4^{\circ} \mathrm{C}$. DLS measurements were recorded on a Zetasizer instrument (Nano ZS; Malvern Instruments) at $20^{\circ} \mathrm{C}$ using a small-volume $(40 \mu \mathrm{l})$ quartz cuvette of $1 \mathrm{~cm}$ path length. Scattering data were collected as an average of 5 measurements with 10 scans for each measurement. Refractive indices were 1.330 (water) and 1.45 (protein) for polydispersant and material, respectively. Data were processed with the Malvern Zetasizer Software (Malvern Instruments).

Structural study by attenuated total reflection-Fourier transform infrared (ATR-FTIR) spectroscopy. A $\beta_{42}$ samples (wt, nitrated with SIN-1 and synthetically nitrated at Tyr10) were prepared as indicated above and kept for $24 \mathrm{~h}$ at $4^{\circ} \mathrm{C}$. They were put in thin hydrated films through an $\mathrm{N} 2$ stream gentle drying. Spectra were obtained at RT by the average of 250 scans at $2 \mathrm{~cm}$ resolution in a VARIAN FTS-7000 infrared spectrometer. The second derivative was performed with 10 smoothing points.

Structural analysis by bioinformatic modeling. The NMR structure 2LMN (Petkova et al., 2006) from the Protein Data Bank (Berman et al., 2000) was used as a template for the structural analysis of $A \beta$. A total of 500 models were built with MODELLER (Webb and Sali, 2014) for $\mathrm{A} \beta_{\mathrm{WT}}$ (wild-type form of the $\mathrm{A} \beta$ peptide) and the mutant $\mathrm{A} \beta_{\mathrm{E} 14}$. We evaluated with ZRANK (Pierce and Weng, 2007) the energies of all the interfaces involving the $\mathrm{A} \beta$ peptides. We observed a destabilization of $\mathrm{A} \beta_{\mathrm{E} 14}$ conformation with respect to $\mathrm{A} \beta_{\mathrm{WT}}$, and we manually oriented the side-chains of $\mathrm{H} 13$ and $\mathrm{E} 14$ to regain the local stabilization (which was confirmed with ZRANK). There is a loss of conformational stability in $\mathrm{A} \beta_{\mathrm{WT}}$ when extending the multipeptide $\beta$-sheet due to the accumulation of identical charges. We postulate that an $n$-peptide complex (complex-1, forming a parallel $\beta$-sheet $\beta 1$ ) packs with another $n$-peptide complex (complex-2, with an opposite parallel $\beta$-sheet $\beta 1^{\prime}$ ) and compensates for the charges. This observation agrees with the notion that phosphorylation of S26 has an effect over amyloid aggregation similar to that of the nitrotyrosination of 
A

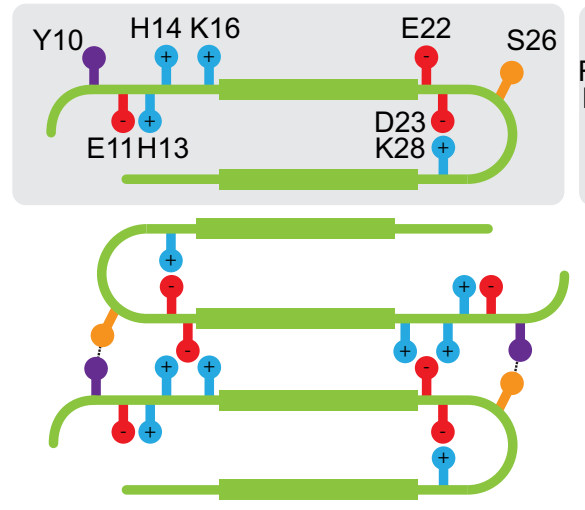

C

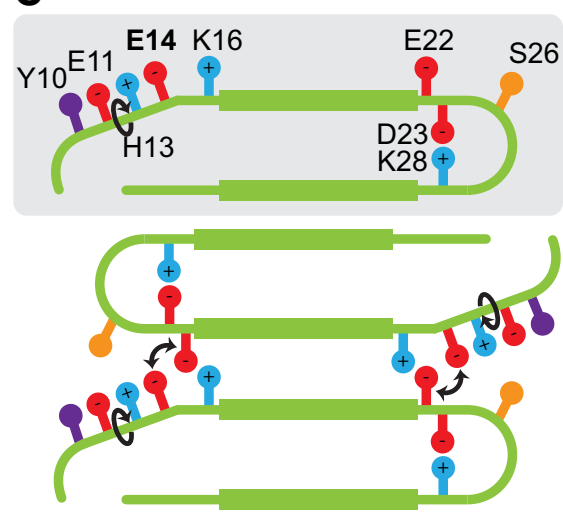

B
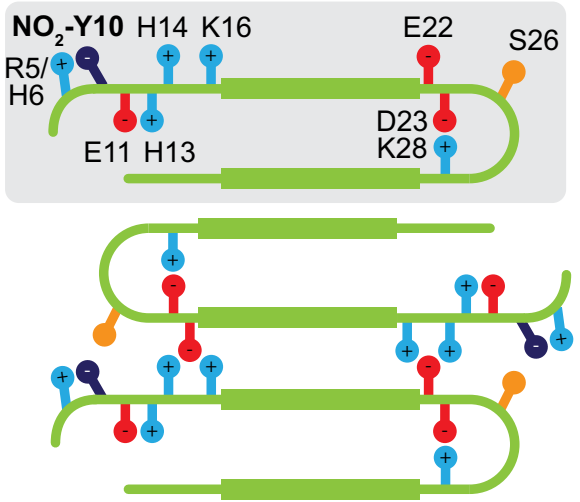

D

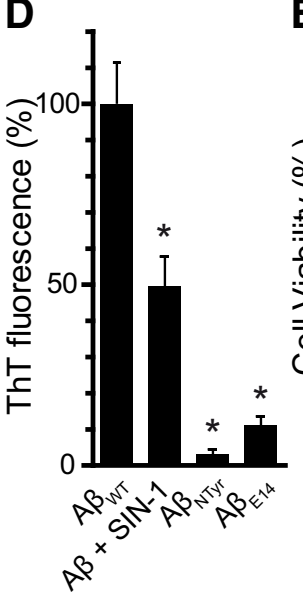

E

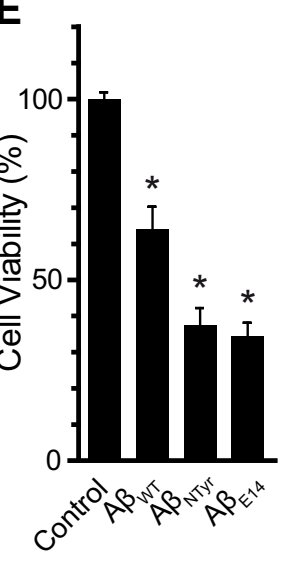

Figure 4. Disruption of $\mathrm{Y} 10-\mathrm{S} 26$ interaction impairs fibril formation. $A$, Model of interprotofibrillar $A \beta_{42}$. The interaction between $\mathrm{Y} 10$ and $\mathrm{S} 26$ stabilizes the fibril and contributes to its progression. $\boldsymbol{B}$, Upon the nitration of $\mathrm{Y} 10$, because the nitro group is negatively charged, it is arrested by the side-chains of either $\mathrm{R} 5$ or $\mathrm{H6}$, impeding its interaction with $\mathrm{S} 26$ and destabilizing the fibril. C, Our mutant $\mathrm{H} 14$ to $\mathrm{E} 14$ also would trigger a rearrangement of the side-chains of the $\mathrm{N}$ terminus, disrupting the interaction between $\mathrm{Y} 10$ and $\mathrm{S} 26$ as it happens upon nitration. $D$, ThT fluorescence after $72 \mathrm{~h}$ of aggregation of $A \beta_{42}, A \beta_{42}$ treated with 100 $\mu \mathrm{M}$ SIN-1, synthetically nitrated $A \beta_{42}\left(A \beta_{\mathrm{NTyy}}\right)$, and $A \beta_{\mathrm{E} 14}$ mutant. Values are expressed as a percentage compared with $A \beta_{42}$. Mean \pm SEM of four independent experiments. ${ }^{*} p<0.001$ (one-way ANOVA using Dunnett's post test). $\boldsymbol{E}$, (ell viability assay performed by the MTT method. Hippocampal neurons were treated with $10 \mu \mathrm{m}$ of $A \beta_{\mathrm{WT}} A \beta_{\mathrm{NTyr}}$ and the mutant $\mathrm{A} \beta_{\mathrm{E} 14}$ for $24 \mathrm{~h}$. Values are expressed as the percentage of the control. Mean \pm SEM of 13-16 independent experiments. ${ }^{*} p<0.001$ (one-way ANOVA using Dunnett's post test).

Y10 (Rezaei-Ghaleh et al., 2014). Then, we suggest that the interaction between Y10 (in complex-1) and S26' (in complex-2) fixes this new configuration. Through static-directed docking with PatchDock (Duhovny et al., 2002), we modeled the packed dimer of complex-1 and complex-2 and analyzed the potential conformations (poses) with ZRANK. The comparison between the wild-type $\left(\mathrm{A} \beta_{\mathrm{WT}}\right)$ and mutant form shows a putative alteration of affinity. Presumably, $\mathrm{A} \beta_{\mathrm{E} 14}$ is less stable, forcing a change of orientation between $\mathrm{Y} 10$ and S26' that separates both residues and dissipates the effect of Y10 nitrotyrosination on fibril formation.

Mouse hippocampal primary cultures and transfection. Mouse hippocampal neurons were isolated from 18-d-old CD1 embryos of either sex. Pregnant mice were killed by $\mathrm{CO}_{2}$ inhalation in accordance with the EC-IMIM-UPF and the directives of the Council of the European Communities 86/609/CEE. Embryos were rendered hypothermic and decapitated. Hippocampi were aseptically dissected in icecold HBSS (Invitrogen) supplemented with $4.5 \mathrm{~g} / \mathrm{L}$ glucose and trypsinized for $17 \mathrm{~min}$ at $37^{\circ} \mathrm{C}$. After 3 washes in HBSS + glucose and mechanical dissociation, cells were seeded in DMEM (Invitrogen) plus $10 \%$ horse serum (Invitrogen) onto $1 \%$ poly-L-lysine-coated plates. After $2 \mathrm{~h}$, medium was removed and Neurobasal medium was added, containing 2\% B27 supplement, 1\% GlutaMAX, and 1\% pen- icillin/streptomycin (Invitrogen). After 3 DIV, neurons were treated with $2 \mu \mathrm{M} \beta$-Darabinofuranosylcytosine (Sigma-Aldrich) for $24 \mathrm{~h}$ to reduce the number of proliferating non-neuronal cells. Primary neuronal cultures were used at 10-14 DIV.

For the $3 \mathrm{D}$ rendering of dendrites, $14 \mathrm{DIV}$ neurons were transfected with the pCAGLifeActTagGFP2 plasmid (Ibidi) using Lipofectamine 2000 (Invitrogen), according to the manufacturer's instructions.

Cell viability study by methylthiazolyldiphenyl-tetrazolium bromide (MTT) assay. Hippocampal neurons were seeded in 48 well plates at a density of $5 \times 10^{5}$ cells/200 $\mu \mathrm{l} /$ well. The corresponding treatments were added to Neurobasal without phenol red supplemented with $1 \%$ GlutaMAX, and cells were incubated for $24 \mathrm{~h}$ at $37^{\circ} \mathrm{C}$ unless indicated otherwise. Cell viability was assessed by MTT reduction. Briefly, $22 \mu$ l of MTT (Sigma-Aldrich) stock solution $(5 \mathrm{mg} / \mathrm{ml})$ was added to the wells; and after $2 \mathrm{~h}$, the media were replaced with $100 \mu \mathrm{l}$ of DMSO to solubilize tetrazolium salts. MTT absorbance was determined in an Infinite 200 multiplate reader (Tecan) at $\mathrm{A} 540 \mathrm{~nm}$ and corrected by $\mathrm{A} 650 \mathrm{~nm}$. Untreated cells were taken as $100 \%$.

Structural analysis by transmission electron microscopy. $\mathrm{A} \beta_{42}$ samples (wt, nitrated with SIN-1, synthetically nitrated at Tyr10 and H14 to E14 mutant; $0.125 \mu \mathrm{g} / \mu \mathrm{l}$ in PBS) were incubated for $72 \mathrm{~h}$ at RT without agitation. Silicon/ Formvar-coated 300-mesh copper grids (Electron Microscopy Sciences) were rendered hydrophilic by being exposed for $20 \mathrm{~min}$ to UV light. Samples were gently agitated before pipetting $5 \mu$ l onto the grids. After 2 min adsorption time, the excess was drawn off using Whatman 541 filter paper (GE Healthcare). The grids were stained with filtered $2 \%$ uranyl acetate (Electron Microscopy Sciences) for 1 min. Excess was drawn off and grids were airdried before examination. Samples were examined with a JEOL 1011 transmission electron microscope at an operating voltage of $80 \mathrm{kV}$.

Cytosolic calcium measurements. Cells were loaded with $250 \mu \mathrm{l}$ fura-2 AM ( $5 \mu \mathrm{M}$; Invitrogen) and $0.02 \%$ pluronic acid for $40 \mathrm{~min}$ at RT and washed thoroughly with isotonic solution containing $2.5 \mathrm{~mm} \mathrm{KCl}, 140 \mathrm{~mm} \mathrm{NaCl}, 1.2 \mathrm{~mm} \mathrm{CaCl}_{2}, 0.5 \mathrm{~mm} \mathrm{MgCl}_{2}$, $5 \mathrm{~mm}$ glucose, and $10 \mathrm{~mm}$ HEPES (305 mOsm, pH 7.4). Experiments were performed at RT using a custom-made recording chamber on an inverted microscope. Excitation at 340 and $380 \mathrm{~nm}$ was supplied by a xenon arc lamp with an optical filter changer. Emitted fluorescence at $510 \mathrm{~nm}$ was recorded every $5 \mathrm{~s}$ using a digital camera controlled by AquaCosmos software. Cytosolic calcium levels are presented as the ratio of emitted fluorescence at $510 \mathrm{~nm}$ following excitation at 340 and $380 \mathrm{~nm}$ (340/380 ratio) and are corrected for the basal individual fluorescence measured before stimulation.

Cell viability study by TUNEL assay. Hippocampal neurons were seeded in 48 -well plates at a density of $5 \times 10^{5} \mathrm{cells} / 200 \mu \mathrm{l} /$ well. Neurons were treated for $5 \mathrm{~min}$ with $10 \mu \mathrm{M} \mathrm{A} \beta_{42}$, prepared as indicated above, washed, and incubated with Neurobasal without phenol red supplemented with $1 \%$ GlutaMAX for $24 \mathrm{~h}$ at $37^{\circ} \mathrm{C}$. Cell viability was assessed $24 \mathrm{~h}$ later with the Click-it TUNEL AlexaFluor-488 imaging assay (Invitrogen), following the manufacturer's instructions. Coverslips were visualized using a Leica TCS SP5 II confocal microscope and analyzed using 
Fiji (Schindelin et al., 2012) distribution of Image (Schneider et al., 2012).

Study of $A \beta$ binding to synaptic spines by immunofluorescence. Hippocampal neurons were seeded in 48 -well plates at a density of $5 \times 10^{5}$ cells/200 $\mu \mathrm{l} /$ well. Neurons were treated for 5 min with the different $\mathrm{A} \beta$ (wt, nitrated with SIN-1 and synthetically nitrated at Tyr 10 ), prepared as indicated above, washed, and incubated with Neurobasal without phenol red supplemented with $1 \%$ GlutaMAX for $24 \mathrm{~h}$ at $37^{\circ} \mathrm{C}$. Neurons were fixed with EM grade methanol-free 4\% PFA in PBS for $15 \mathrm{~min}$ at RT. Samples were blocked with $0.3 \%$ Triton X-100 and 5\% normal goat serum (Vector) for $1 \mathrm{~h}$ at RT. Then they were probed overnight with 1:200 $6 \mathrm{E} 10$ anti-A $\beta$ and $1: 1000$ rabbit polyclonal anti-GFP antibody (Sigma) at $4^{\circ} \mathrm{C}$. Alexa-488-conjugated goat anti-rabbit and Alexa-555-conjugated goat anti-mouse secondary antibodies (1:1000, Invitrogen) were used at RT for $1 \mathrm{~h}$. Coverslips were mounted using Fluoromount-G (eBioscience) and observed with a Leica TCS SP5 II confocal microscope. Deconvolution of the $z$-stacks was performed with Huygens deconvolution software (SVI), 3D rendering was performed with Imaris (Bitplane), and colocalization was analyzed using JaCoP plugin (Bolte and Cordelières, 2006) for ImageJ.

Study of $A \beta$ binding to synaptic spine by Manders' coefficient measurement. Manders' coefficients were calculated in the experiments of colocalization of spines and $\mathrm{A} \beta$ by immunofluorescence. They measure the overlap of two different immunofluorescence channels: green and magenta stainings for spines and $\mathrm{A} \beta$, respectively. Therefore, we calculated the overlapping of the green channel (GFP) with the magenta channel $(A \beta)$ as previously described (Ill-Raga et al., 2015). It is expressed in arbitrary units from 0 to 1 , with 0 being a lack of overlap and 1 being the maximum overlap.

Study of $A \beta$ binding to GluN1 by immunoprecipitation. Hippocampal neurons were seeded in 48 -well plates at a density of $5 \times 10^{5}$ cells/200 $\mu \mathrm{l} /$ well. Neurons were treated for $5 \mathrm{~min}$ with the different $\mathrm{A} \beta$ (wt, nitrated with SIN-1 and synthetically nitrated at Tyr 10), prepared as indicated above, washed, and incubated with Neurobasal without phenol red supplemented with $1 \%$ GlutaMAX for $24 \mathrm{~h}$ at $37^{\circ} \mathrm{C}$. Cells were washed three times in PBS and lysed with ice-cold 1\% Triton X-100 PBS with protease inhibitor mixture (Roche). GluN1 was immunoprecipitated with the mouse monoclonal anti-GluN1 antibody and magnetic beads (Invitrogen), using a modified protocol of the manufacturer's instructions. Briefly, $2 \mu \mathrm{g}$ of antibody was bound to $1.5 \mathrm{mg}$ Dynabeads Protein $\mathrm{G}$ in $200 \mu \mathrm{l}$ of Tween $20 \mathrm{PBS}$ for $1 \mathrm{~h}$ at RT. The beads were washed and incubated overnight with $500 \mu \mathrm{l}$ of lysate at $4^{\circ} \mathrm{C}$. The supernatant was removed, the beads were washed thoroughly, and the antigen was eluted with a 67:30:3 mixture of $50 \mathrm{~mm}$ glycine, $\mathrm{pH}$ 2.8, LDS Sample Buffer and Reducing Agent (Invitrogen), and incubated at $70^{\circ} \mathrm{C}$ for $10 \mathrm{~min}$ before running the samples in a protein gel.

Statistical analysis. Data are expressed as mean \pm SEM of $n$ experiments. Statistical analyses were performed with one-way ANOVA using GraphPad software, unless indicated otherwise.

\section{Results}

\section{$\mathrm{A} \boldsymbol{\beta}$ nitrotyrosination impairs fibril formation and stabilizes low molecular weight oligomers}

Previous studies have shown the presence of nitrotyrosinated $\mathrm{A} \beta$ in $\mathrm{AD}$ brains and have nitrotyrosinated $\mathrm{A} \beta$ in vitro treated with pure peroxynitrite (Kummer et al., 2011). We were able to ob- serve nitrotyrosine immunoreactivity in the plaques of $\mathrm{AD}$ patients (Fig. 1A). In addition, we wanted to determine whether the peroxynitrite donor SIN- 1 also nitrotyrosinates $A \beta$ in vitro, since pure peroxynitrite is more unstable (Szabó et al., 2007). Using a nitrotyrosine-specific antibody and dot blot analysis, we were able to detect $A \beta$ nitrotyrosination using increasing concentrations of SIN-1 (Fig. 1B).

Nitrotyrosination is well known to alter protein function; we hypothesized that peroxynitrite may alter A $\beta$ aggregation. ThT measurements are useful to quantitatively assess the content of $\beta$-sheet-rich structures and are widely used to evaluate $\mathrm{A} \beta$ progression to fibrils. We assayed the aggregation of $A \beta$ over time in the presence of increasing concentrations of SIN-1 and found that nitrotyrosination avoids fibrillation and favors oligomer formation (Fig. $1 C$ ). Untreated $\mathrm{A} \beta$ reached the plateau phase of the sigmoidal curve within $10 \mathrm{~h}$ of aggregation, which is consistent with the literature (Cohen et al., 2013), whereas peroxynitritetreated $\mathrm{A} \beta$ showed remarkably decreased aggregation rates in a concentration-dependent manner. Moreover, fluorescence ThT values for treated $\mathrm{A} \beta$ remained similarly low after 1 week of aggregation (data not shown). Because we observed strong $\mathrm{A} \beta$ nitrotyrosination at $100 \mu \mathrm{M} \mathrm{SIN-1} \mathrm{concentration}(p<0.01)$ and in parallel the aggregation rates at the plateau phase were significantly reduced (Fig. 1D), we chose this concentration for the detailed study of nitrotyrosinated $\mathrm{A} \beta$ (nitro- $\mathrm{A} \beta$ ).

Our aggregation data with ThT pointed toward a clear enhancement of oligomerization and inhibition of $\mathrm{A} \beta$ aggregation upon nitrotyrosination. Focusing on soluble low molecular weight $\mathrm{A} \beta$ oligomeric species, we assayed $\mathrm{A} \beta$ and nitro- $\mathrm{A} \beta$ samples at different time points of aggregation and proceeded to blot them with the $6 \mathrm{E} 10$ monoclonal anti-A $\beta$ antibody. Although dimers are not strictly oli- 

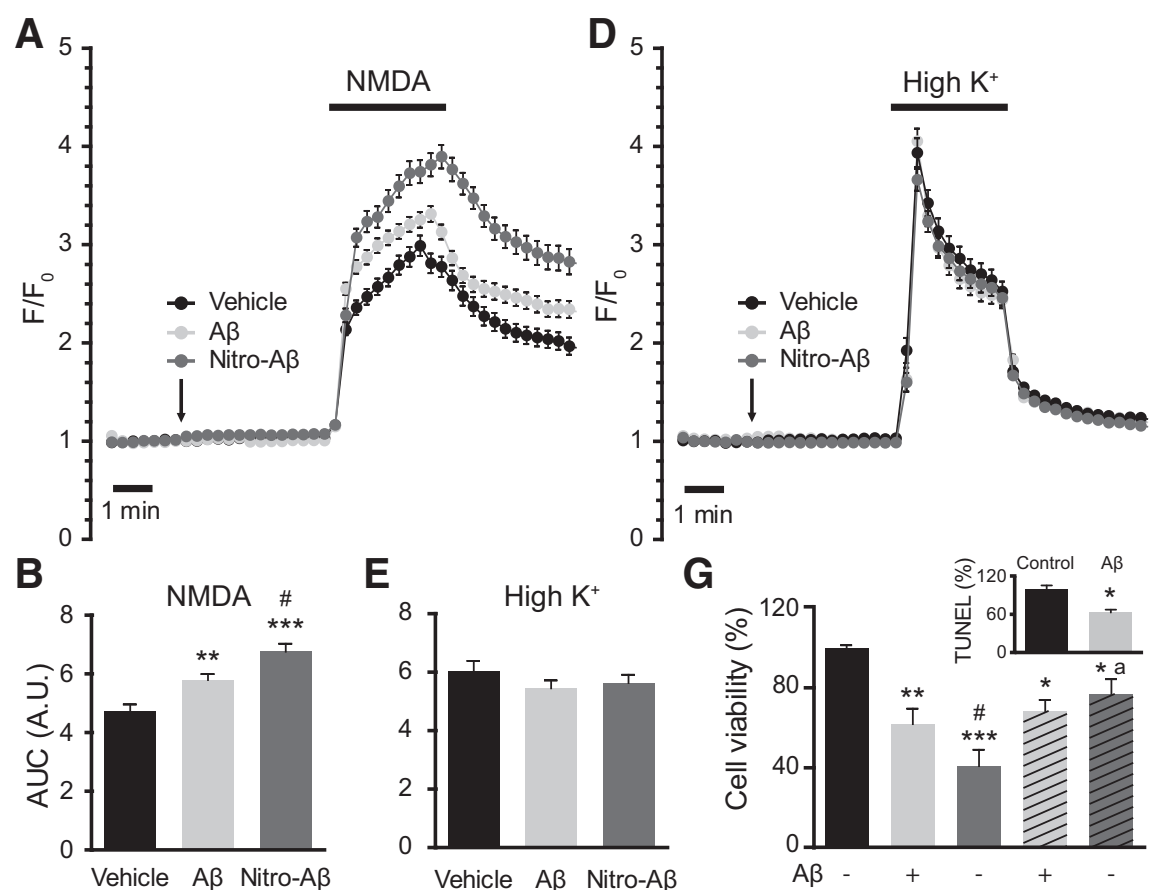

E

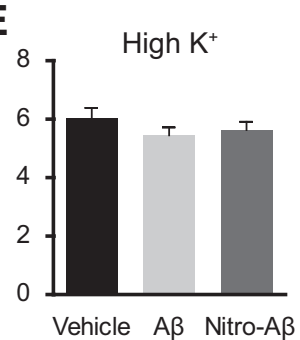

G
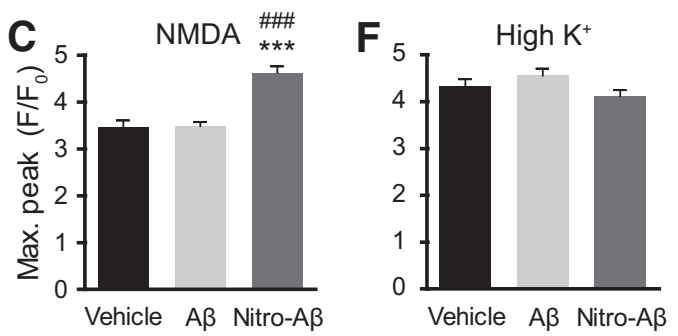

H

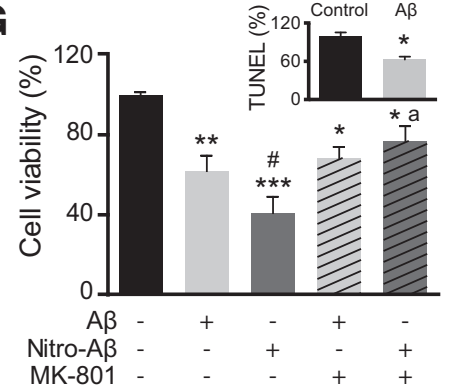

(1)

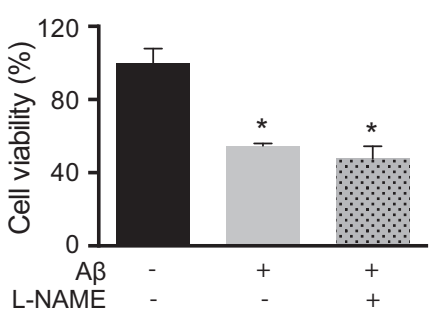

Figure 6. Nitro-A $\beta$ oligomers affect calcium homeostasis and exert NMDA-dependent toxicity. Cells were treated for 5 min with $10 \mu \mathrm{M} \mathrm{A} \beta$ or nitro-A $\beta$ and stimulated with bath application of either $100 \mu \mathrm{MNMDA}(\boldsymbol{A})$ or $52.5 \mu \mathrm{M} \mathrm{KCl}$ (D). Mean \pm SEM of 82-87 cells for NMDA and 98-104 for KCl. The area under the curve (AUC) $(\boldsymbol{B}, \boldsymbol{C})$ and the maximum response peak $(\boldsymbol{E}, \boldsymbol{F})$ were calculated for each cell response. $G$, Cell viability assay performed by the MTT method. Hippocampal neurons were treated with 10 $\mu \mathrm{M} A \beta$ and nitro- $\mathrm{A} \beta$ with or without $10 \mu \mathrm{M}$ MK-801 for $5 \mathrm{~min}$, and cell viability was assessed after $24 \mathrm{~h}$. Untreated neurons were taken as $100 \%$ of viability. Inset, $A$ control of $A \beta$ toxicity studied by TUNEL assay. Mean \pm SEM of three or four independent experiments. $\boldsymbol{H}$, Cell viability assayed with the MTT method in hippocampal neurons treated with A $\beta$ in the presence or absence of the NOS inhibitor L-NAME for $5 \mathrm{~min}$. Cell viability was assessed after $24 \mathrm{~h}$. Mean \pm SEM of three independent experiments. ${ }^{*} p<$ 0.05 , compared with control (one-way ANOVA using Newman-Keuls post test). ${ }^{* *} p<0.01$, compared with control (one-way ANOVA using Newman-Keuls post test). ${ }^{* * *} p<0.001$, compared with control (one-way ANOVA using Newman-Keuls post test). ${ }^{\#} p<0.05$, compared with A $\beta$ (one-way ANOVA using Newman-Keuls post test). ${ }^{\# \#} p<0.001$, compared with A $\beta$ (one-way ANOVA using Newman-Keuls post test). ${ }^{a} p<0.05$ compared with nitro-A $\beta$ by (one-way ANOVA using Newman-Keuls post test). Student's t test for the TUNEL study.

gomers, for the sake of simplicity, they will be referred to as such, together with trimers, tetramers, and other low molecular weight oligomeric species. Over time, the untreated $\mathrm{A} \beta$ low molecular weight oligomers tended to give way to the formation of larger aggregates, whereas the nitro- $\mathrm{A} \beta$ low molecular weight oligomers remained stable (Fig. 2A,B). This was further confirmed when these oligomers were visualized on freshly cleaved mica with AFM. In the case of untreated $\mathrm{A} \beta$ (Fig. $2 C$ ), the oligomers that remained stable after $72 \mathrm{~h}$ of aggregation for nitro-A $\beta$ could not be seen. Overall, these results are in good agreement with our data regarding $A \beta$ and nitro-A $\beta$ aggregation (Fig. $1 C, D$ ). Particle size distribution by DLS shows that nytrotyrosinated and wild-type samples are very polydisperse (Fig. 3A), indicative of the existence of several size species. For wild-type samples, the presence of at least two populations (150 and $450 \mathrm{~nm}$ ) contrasts with the nytrotyrosinated samples with a popula- tion more centered in the $150-250 \mathrm{~nm}$ region, in agreement with the NuPAGE data in Figure 1. Secondary structure analysis for nitrotyrosinated and wild-type $\mathrm{A} \beta_{42}$ shows a predominant $\beta$-sheet structure for all samples both by CD (Fig. 3B) and FTIR (Fig. 3C). CD-positive band at $200 \mathrm{~nm}$ and negative band at $225 \mathrm{~nm}$ representative of $\beta$-sheet secondary structure agree fairly well with the observed ATR-FTIR absorbance spectrum indicative of $\beta$-sheet structure with prominent peaks at 1625 and $1695 \mathrm{~cm}$ (Fig. 3C). For the sake of clarity, the ATRFTIR spectra second derivative is shown for all samples (Fig. 3D). The 1625/1695 cm band splitting indicative of aggregation (Perálvarez-Marín et al., 2008) is highlighted showing a larger splitting (i.e., larger aggregation) for $\mathrm{A} \beta_{42}(1698$ and $1624 \mathrm{~cm})$. $\mathrm{A} \beta$ Ntyr and SIN 1 treated band splitting are 1695 and $1628 \mathrm{~cm}$ and 1695 and $1629 \mathrm{~cm}$, respectively, indicative of lesser aggregation. The ATR-FTIR data are in agreement with NuPAGE and DLS data in Figures 1 and $3 A$. Our next step was to explore the molecular basis for these observed behaviors.

\section{Disruption of Y10-S26 interaction impairs fibril formation}

According to the experimentally determined $\mathrm{A} \beta_{42}$ fibril structure (PDB ID: $2 \mathrm{BEG})$, there are two antiparallel $\beta$-sheets comprising residues L17-S26 $(\beta 1)$ and I31-I41 $(\beta 2)$. This complex is stabilized hydrophobically and by intermolecular salt bridges (between D23 and K28) and backbone $\mathrm{H}$ bonds (Lührs et al., 2005). However, protofibrils require further stabilization with interprotofilament interactions to conform the supramolecular architecture of the fibril. Indeed, the structurally heterogeneous fragment D1H16 could possibly be involved in these interactions (Egnaczyk et al., 2001; Zhang et al., 2009). Here, we propose a model in which the interprotofilament interaction of Y10 and S26 is key to the elongation of the fibril (Fig. 4A). We hypothesized that, upon nitration of Y10, this interaction is lost, dramatically impairing fibril stability and thus fibril formation (Fig. 4B).

Impaired fibrillation ability also has been reported in the S26 mutant (Rezaei-Ghaleh et al., 2014). Thus, we tried to mimic the effect of Y10 nitration by using a different strategy to avoid Y10S26 interaction. By mutating $\mathrm{H} 14$ to $\mathrm{E}\left(\mathrm{A} \beta_{\mathrm{E} 14}\right)$, we expected the side-chains of the $\mathrm{N}$ terminus to rearrange, avoiding the interaction between Y10 and S26 (Fig. 4C). We synthesized A $\beta_{\mathrm{E} 14}$ as well as an $\mathrm{A} \beta$ analog with nitrotyrosine in position $10\left(\mathrm{~A} \beta_{\mathrm{NTyr}}\right)$ to check whether the effects on fibril formation impairment and oligomer stabilization were the same as those observed using in vitro nitration with SIN-1.

To evaluate the aggregation propensity of the mutants, we measured ThT fluorescence after $72 \mathrm{~h}$ of aggregation. We observed that fibril formation was reduced to half in $\mathrm{A} \beta$ treated with 


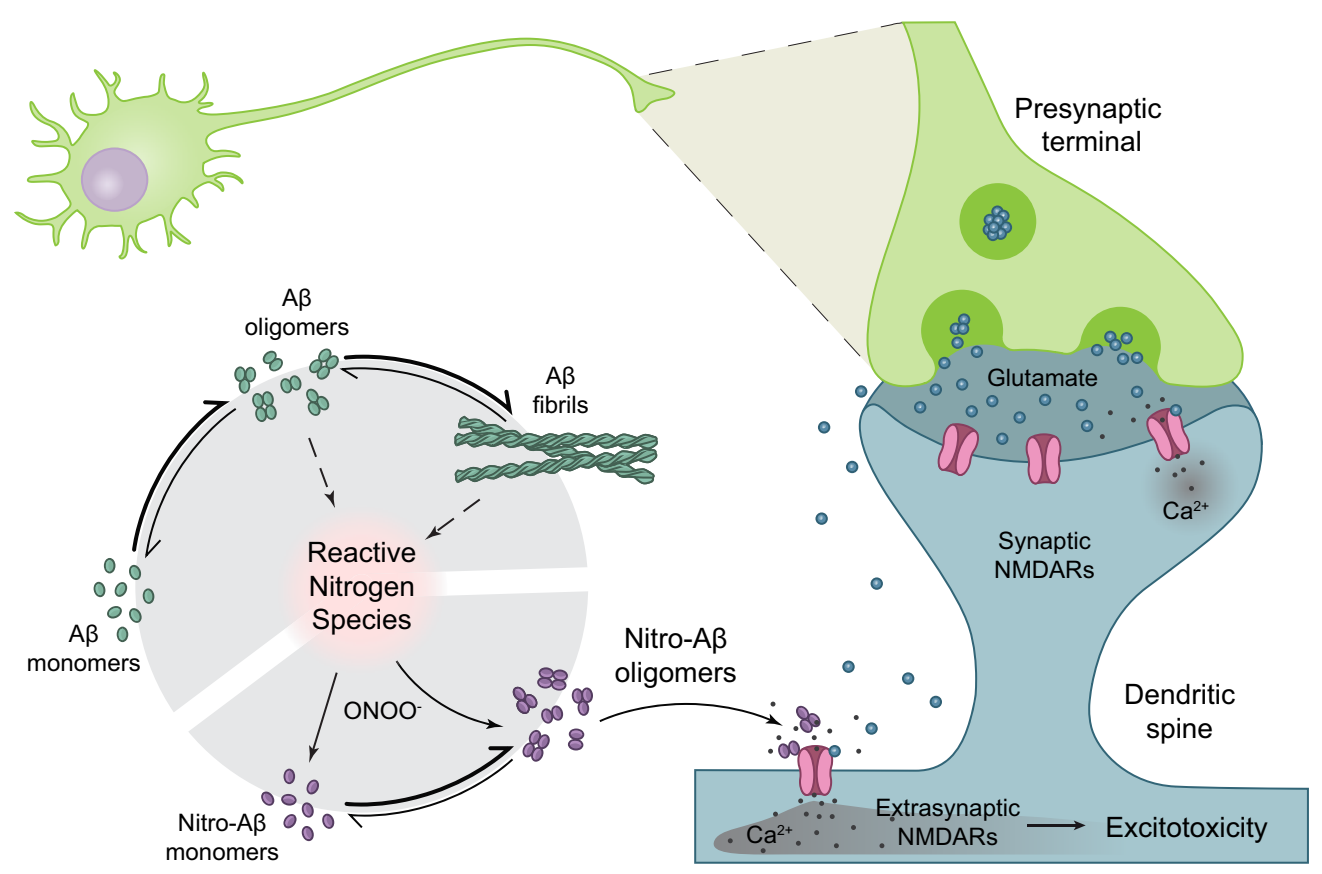

Figure 7. A $\beta$ oligomers and fibrils trigger the formation of nitrogen reactive species. In this context, peroxynitrite reacts with proteins, affecting their function. One of these modifications is protein nitrotyrosination, which is highly promoted in $A D$ brains. $A \beta$ has a potential nitration site in $\mathrm{Y} 10$ and is nitrated in the disease. Nitrotyrosination of $A \beta$ impairs amyloid fibril formation and stabilizes soluble, highly toxic oligomers. Glutamatergic synapses are the most abundant within the hippocampus and the first to be affected in AD. Glutamate is released from the presynaptic neuron into the synaptic cleft; and when it is released in a large quantity, it spills to the perisynaptic space, partially activating extrasynaptic NMDARs. When glutamatergic stimulation is particularly high, and especially when extrasynaptic NMDARs are activated, the excitotoxic apoptotic pathway is triggered. Nitro-A $\beta$ oligomers make the neurons more susceptible to excitotoxic insults.

$100 \mu \mathrm{M}$ SIN-1, compared with the control (Fig. 4D), which is consistent with our time course ThT data (Fig. 1). With $\mathrm{A} \beta_{\mathrm{NTyr}}$, which is synthetically nitrotyrosinated and thus modified in $100 \%$ of the molecules, amyloid fibril formation was almost completely nonexistent, as hypothesized. $\mathrm{A} \beta_{\mathrm{E} 14}$ also had significantly reduced aggregation rates compared with untreated $\mathrm{A} \beta_{\mathrm{WT}}$.

Regarding neuronal toxicity, we treated mouse hippocampal neurons with oligomer preparations from $A \beta_{\mathrm{WT}}, \mathrm{A} \beta_{\mathrm{NTyr}}$, and $\mathrm{A} \beta_{\mathrm{E} 14}$ for $24 \mathrm{~h}$ and evaluated cell viability (Fig. $4 E$ ). In both cases, the mutants were significantly more toxic than untreated $A \beta_{W T}$, suggesting the presence of a soluble, more toxic form of $\mathrm{A} \beta$.

To explore their structure, we examined untreated $\mathrm{A} \beta_{\mathrm{WT}}$, SIN-1 treated $\mathrm{A} \beta_{\mathrm{WT}}, \mathrm{A} \beta_{\mathrm{NTyr}}$, and $\mathrm{A} \beta_{\mathrm{E} 14}$ (Fig. 5) under a transmission electron microscope after $72 \mathrm{~h}$ of aggregation. With untreated $\mathrm{A} \beta_{\mathrm{WT}}$ (Fig. $5 A$ ), we could see mature, amyloid fibrils; but with $\mathrm{A} \beta_{\mathrm{NTyr}}$ (Fig. $5 C$ ) and $\mathrm{A} \beta_{\mathrm{E} 14}$ (Fig. $5 D$ ), we were unable to depict fibrils in any field. Nevertheless, the presence of oligomers was clear in both cases, as well as when $\mathrm{A} \beta_{\mathrm{WT}}$ was nitrotyrosinated (Fig. 5B).

\section{Nitro-A $\beta$ oligomers affect calcium homeostasis and exert NMDA-dependent toxicity}

Oligomers are accepted to be the neuroactive, synaptically toxic form of $\mathrm{A} \beta$. Dimers, trimers, tetramers, dodecamers, and $\mathrm{A} \beta$ derived diffusible ligands have all been suggested as the molecular determinant of $\mathrm{A} \beta$ toxicity. As all coexist in microenvironments of the AD brain, it is difficult to make sharp distinctions between them. Aggregation is a dynamic process, and working with one only form of $\mathrm{A} \beta$ oligomer, even in vitro, can be misleading unless it is cross-linked and thoroughly purified. Given that a mixture of oligomeric species has greater physiological relevance and that finding the molecule responsible for $A \beta$ toxicity is beyond the scope of this work, we assessed nitro-A $\beta$ toxicity using high, acute doses of a heterogeneous oligomer preparation.
Considering that $\mathrm{A} \beta$ oligomers have been linked to calcium dyshomeostasis and that NMDAR plays a key role not only in synaptic plasticity but also in $\mathrm{AD}$, we explored the effect of acute, high-concentration $\mathrm{A} \beta$ and nitro- $\mathrm{A} \beta$ oligomer treatment on hippocampal cultured cells. Ten DIV mouse hippocampal neurons were loaded with the cytosolic calcium dye fura-2 AM. A $10 \mu \mathrm{M}$ (monomer equivalent) oligomer preparation of either $\mathrm{A} \beta$ or nitro-A $\beta$ was applied extracellularly for $5 \mathrm{~min}$. Surprisingly, we observed no cytosolic calcium changes upon the bath application of $\mathrm{A} \beta$ or nitro-A $\beta$ (Fig. $6 A, D$ ). However, subsequent stimulation with the NMDAR synthetic agonist NMDA generated an increased response upon $\mathrm{A} \beta$ treatment and even larger responses in the case of nitro- $\mathrm{A} \beta$ treatment (Fig. $6 A-C$ ). Nevertheless, this effect was not observed when cells were stimulated with another physiological stimulus. Upon application of a high potassium solution, which activates voltage-dependent calcium channels, we did not observe differences in calcium responses (Fig. 6D-F). Thus, it appears that this effect is specific, although perhaps not exclusive, to NMDAR.

Having observed that differences in NMDA-induced calcium responses and extrasynaptic NMDARs can trigger excitotoxicity, we wanted to assess whether the nitro- $\mathrm{A} \beta$ insult made the neurons more susceptible to excitotoxicity using the NMDAR blocker MK-801. Similarly to calcium-imaging experiments, we treated the cells with $\mathrm{A} \beta$ and nitro- $\mathrm{A} \beta$ oligomers with or without MK-801, replaced the media after $5 \mathrm{~min}$ and evaluated cell viability after $24 \mathrm{~h}$ (Fig. $6 G$ ). Strikingly, $5 \mathrm{~min}$ of oligomer exposure was sufficient to trigger neuronal cell death. In addition, NMDA was partially responsible for $\mathrm{A} \beta$ oligomer toxicity, as toxicity was slightly reverted with $\mathrm{MK}-801$. On the other hand, nitro-A $\beta$ oligomers were significantly more toxic compared with $\mathrm{A} \beta$, and cotreatment with MK-801 restored cell viability to the levels of $\mathrm{A} \beta$ plus $\mathrm{MK}-801$. Therefore, it seems that the difference in cell viability between $A \beta$ and nitro- $A \beta$ oligomers was entirely 
A

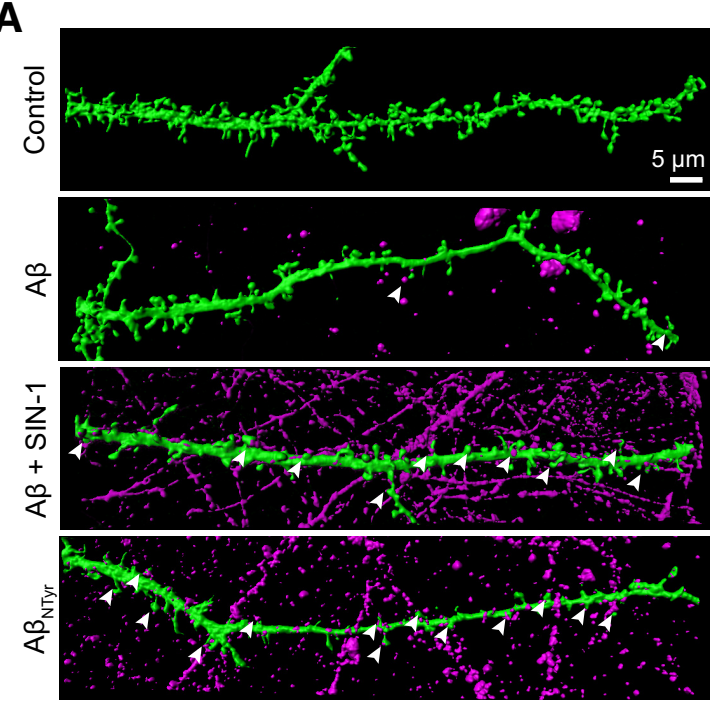

C

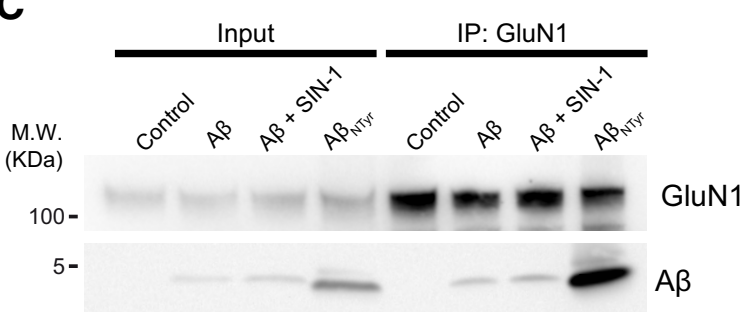

B
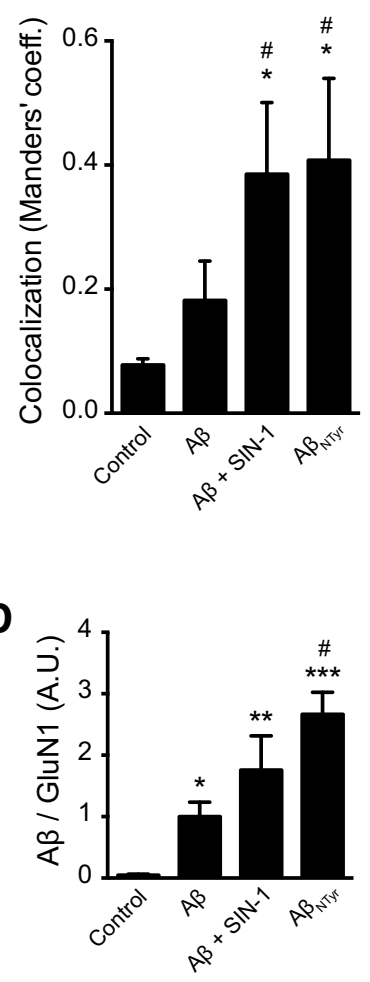

Figure 8. Increased nitro-A $\beta$ oligomers binding to the synapses. Cells were treated for 5 min with $10 \mu \mathrm{M} A \beta$ or nitro-A $\beta$ (SIN-1-treated $A \beta$ and $A \beta_{\mathrm{NTyr}}$ ). $A$, Three-dimensional rendering of dendritic spines. Green represents the neuron volume (GFP). Magenta represents $A \beta$ and nitro-A $\beta$ oligomers. Nitro- $A \beta$ oligomers contact the dendritic spines (arrows). $B$, Colocalization analysis of $A$. M1 Manders' coefficient refers to the fraction of $A \beta$ overlapping spines. Mean \pm SEM of $5-8$ neurons from three different experiments. $C$, Representative Western blot of $A \beta$ and nitro-A $\beta$ coimmunoprecipitated with the NMDAR subunit GluN1 from hippocampal neurons. $\boldsymbol{D}$, Quantification of $\boldsymbol{C}$. Mean \pm SEM of 5-7 independent experiments. ${ }^{*} p<0.05$, compared with control (one-way ANOVA using Newman-Keuls post test). ${ }^{* *} p<0.01$, compared with control (one-way ANOVA using NewmanKeuls post test). ${ }^{* * *} p<0.001$, compared with control (one-way ANOVA using Newman-Keuls post test). ${ }^{*} p<0.01$, compared with $A \beta$ (one-way ANOVA using Newman-Keuls post test).

NMDAR-dependent. A control on the accuracy of MTT method to measure cell death was performed by TUNEL assay (Fig. $6 A$, inset), resulting both in a drop of $\sim 40 \%$ in cell viability with $\mathrm{A} \beta$. Furthermore, to address whether NO release by NOS is involved in the toxicity associated to $\mathrm{A} \beta$, we performed a cell viability assay combining the treatment of $\mathrm{A} \beta$ with the NOS inhibitor L-NAME (Fig. $6 H$ ). However, we were not able to observe a prevention of $\mathrm{A} \beta$ toxicity. Hence, nitrotyrosination of $\mathrm{A} \beta$ inhibits fibrillation, stabilizing a soluble, highly toxic form of nitro-A $\beta$ oligomers that make neurons more susceptible to excitotoxic insults (Fig. 7).

We hypothesized that the differences we observed in excitotoxicity and in the NMDAR-dependent intracellular calcium increase could be due to an increased binding of nitro-A $\beta$ oligomers to the synapses and, more specifically, to NMDAR. To address this hypothesis, we transfected hippocampal neurons with GFP and treated them with or without $A \beta$ and nitro- $A \beta$ for $5 \mathrm{~min}$. We performed $3 \mathrm{D}$ rendering of confocal microscopy stacks of the dendritic spines to visualize the binding of $\mathrm{A} \beta$ and nitro- $\mathrm{A} \beta$ to the dendrites and spines (Fig. 8A). We observed an increased binding of oligomers when neurons were treated with nitro-A $\beta$ (both SIN-1 treated $A \beta$ and $\mathrm{A} \beta_{\mathrm{NTYr}}$ ) compared with $\mathrm{A} \beta$ (Fig. $8 \mathrm{~B}$ ). Even for the neurons that were not transfected, the shape of the spines was visible because of the nitro- $\mathrm{A} \beta$ bound to the dendritic shaft. We obtained similar results when we immunoprecipitated the NMDAR subunit GluN1 from hippocampal neurons and checked the amount of bound $\mathrm{A} \beta$ and the nitrated forms of $\mathrm{A} \beta$ by Western blot (Fig. 8C,D).

\section{Discussion}

There are two main reasons to believe that nitro-oxidative stress is an etiopathogenic factor in AD (Dawson and Dawson, 1996; Smith et al., 1997; Miranda et al., 2000; Tamagno et al., 2002; Coma et al., 2008; Guix et al., 2009). First, aging is the major risk factor for $\mathrm{AD}$ and is associated with an unbalanced redox state due to the failure of antioxidant mechanisms (Hensley et al., 1994). Second, oxidative stress increases APP cleavage by raising the expression of BACE-1 and, as a consequence, enhances the production of both $\mathrm{A} \beta_{42}$ and $\mathrm{A} \beta_{40}$ (Tamagno et al., 2002; Coma et al., 2008), but nitro-oxidative stress increases the $\mathrm{A} \beta_{42} /$ $\mathrm{A} \beta_{40}$ ratio (Guix et al., 2012).

Our findings revealed that $A \beta$ nitrotyrosination impairs fibrillation dramatically, favoring the presence of toxic soluble oligomers. As described by Kummer et al. (2011), A $\beta$ is nitrated at $\mathrm{Y} 10$ in AD brains; they observed nitrotyrosinated $\mathrm{A} \beta$ at the core of amyloid plaques in a triple transgenic mouse model. Our results are in good agreement with their findings regarding the increased toxicity, synaptic failure, and memory impairment caused by nitro-A $\beta$. However, in our study, nitro-A $\beta$ did not progress to mature amyloid fibrils, producing low or virtually no signals in ThT assays. Furthermore, Zhao et al. (2015) have reported that nitration of $\mathrm{A} \beta_{40}$ seems to provoke impaired fibrillation by ThT assays and transmission electron microscopy. Therefore, given that the most toxic and neuroactive forms of $A \beta$ are low molecular weight oligomeric species (Selkoe, 2008; Shankar et al., 2008; Li et al., 2009), our findings support the observed increase of soluble oligomers, rather than fibril formation.

In addition, our results show that nitro- $\mathrm{A} \beta$ oligomers exert higher toxicity in hippocampal neuronal primary cultures through an NMDAR-dependent mechanism. We hypothesize that the binding of $A \beta$ oligomers, and specially of those of nitrated $A \beta$, depends directly on their hydrophobic nature (Serpel, 2000), allowing them to interact with the hydrophobic domains of the extracellular regions of GluN1 and GluN2B (Costa et al., 2012). This interaction would impair the proper and rapid closing of the NMDAR; an effect increased when $A \beta$ oligomers are nitrated. NMDAR plays a key role in $\mathrm{AD}$ because glutamate is the most abundant neurotransmitter in the hippocampus; furthermore, one of the few treatments available for $\mathrm{AD}$ is the mild NMDAR inhibitor memantine. NMDAR overactivation leads to a particular apoptotic pathway known as excitotoxicity (Choi, 1985). Many researchers have explored calcium dyshomeostasis as one of the factors responsible for neurodegeneration in AD (Berridge, 2010). 
Here, we propose a model by which the addition of a nitro group to Y10 would prevent its interaction with S26, leading to the destabilization of interprotofibrillar contacts and impairing the progression to amyloid fibrils. The phosphorylation of S26 or its replacement with another amino acid have been reported to impair the capacity to form amyloid fibrils (Rezaei-Ghaleh et al., 2014). We show how the disruption of Y10-S26 interaction by mutating H14 to E14 not only impairs fibril formation but also mimics nitro-A $\beta$ in terms of neurotoxicity.

In terms of the structure of the $\mathrm{A} \beta$ fibrils, it has been demonstrated that oligomers are the most toxic amyloid aggregate forms. The formation of senile plaques by mature amyloid fibrils could be a mechanism to eliminate oligomers from the neuronal surroundings (Fernàndez-Busquets, 2013). We found that $\mathrm{A} \beta_{42}$ oligomers are stabilized by the presence of peroxynitrite, by using the peroxynitrite donor SIN-1, which delays the formation of mature $A \beta$ fibrils. It resembles the pathological scenario leading to APP cleavage on the glutamatergic synapses in $\mathrm{AD}$, where sustained NO production causes the oxidative stress. Thus, these nitrotyrosinated oligomers could be especially toxic to the brain because they exist in a more toxic conformation for a longer period than do non-nitrated oligomers that rapidly aggregate to form mature fibrils, a less toxic amyloid aggregate form.

In conclusion, our data support the role of peroxynitrite as a factor with an impact on $\mathrm{AD}$ pathophysiology at several levels. We propose a mechanism for $\mathrm{A} \beta$ toxicity that is relevant for $\mathrm{AD}$ pathophysiology because nitro- $\mathrm{A} \beta$ has been found in amyloid plaques. We also suggest a model for the assembly of $A \beta$ fibrils, in which the aggregation is severely impaired by the disruption of the interprotofibrillar interaction between Y10 and S26. These nitrotyrosinated oligomers remain stable over time, thus preserving the higher toxicity of these shorter amyloid aggregates, compared with mature amyloid fibrils.

\section{References}

Arimon M, Díez-Pérez I, Kogan MJ, Durany N, Giralt E, Sanz F, FernàndezBusquets X (2005) Fine structure study of A $\beta 1-42$ fibrillogenesis with atomic force microscopy. FASEB J 19:1344-1346. CrossRef Medline

Beckman JS, Koppenol WH (1996) Nitric oxide, superoxide, and peroxynitrite: the good, the bad, and ugly. Am J Physiol 271:C1424-C1437. Medline

Berman HM, Westbrook J, Feng Z, Gilliland G, Bhat TN, Weissig H, Shindyalov IN, Bourne PE (2000) The Protein Data Bank. Nucleic Acids Res 28:235-242. CrossRef Medline

Berridge MJ (2010) Calcium hypothesis of Alzheimer's disease. Pflugers Arch 459:441-449. CrossRef Medline

Bitan G, Teplow DB (2005) Preparation of aggregate-free, low molecular weight amyloid-beta for assembly and toxicity assays. Methods Mol Biol 299:3-9. Medline

Bolte S, Cordelières FP (2006) A guided tour into subcellular colocalization analysis in light microscopy. J Microsc 224:213-232. CrossRef Medline

Byler DM, Susi H (1986) Examination of the secondary structure of proteins by deconvolved FTIR spectra. Biopolymers 25:469-487. CrossRef Medline

Castegna A, Thongboonkerd V, Klein JB, Lynn B, Markesbery WR, Butterfield DA (2003) Proteomic identification of nitrated proteins in Alzheimer's disease brain. J Neurochem 85:1394-1401. CrossRef Medline

Choi DW (1985) Glutamate neurotoxicity in cortical cell culture is calcium dependent. Neurosci Lett 58:293-297. CrossRef Medline

Cohen SI, Linse S, Luheshi LM, Hellstrand E, White DA, Rajah L, Otzen DE, Vendruscolo M, Dobson CM, Knowles TP (2013) Proliferation of amyloid- $\beta 42$ aggregates occurs through a secondary nucleation mechanism. Proc Natl Acad Sci U S A 110:9758-9763. CrossRef Medline

Coma M, Guix FX, Ill-Raga G, Uribesalgo I, Alameda F, Valverde MA, Muñoz FJ (2008) Oxidative stress triggers the amyloidogenic pathway in human vascular smooth muscle cells. Neurobiol Aging 29:969-980. CrossRef Medline

Costa RO, Lacor PN, Ferreira IL, Resende R, Auberson YP, Klein WL, Oliveira CR, Rego AC, Pereira CM (2012) Endoplasmic reticulum stress occurs downstream of GluN2B subunit of $N$-methyl-D-aspartate receptor in mature hippocampal cultures treated with amyloid- $\beta$ oligomers. Aging Cell 11:823-833. CrossRef Medline

Danysz W, Parsons CG (2012) Alzheimer's disease, $\beta$-amyloid, glutamate, NMDA receptors and memantine-searching for the connections. Br J Pharmacol 167:324-352. CrossRef Medline

Dawson VL, Dawson TM (1996) Nitric oxide neurotoxicity. J Chem Neuroanat 10:179-190. CrossRef Medline

Duhovny D, Nussinov R, Wolfson H (2002) Efficient unbound docking of rigid molecules. In: Algorithms in bioinformatics SE-14, pp 185-200. Lecture Notes in Computer Science. Berlin: Springer.

Egnaczyk GF, Greis KD, Stimson ER, Maggio JE (2001) Photoaffinity crosslinking of Alzheimer's disease amyloid fibrils reveals interstrand contact regions between assembled $\beta$-amyloid peptide subunits. Biochemistry 40:11706-11714. CrossRef Medline

Esposito Z, Belli L, Toniolo S, Sancesario G, Bianconi C, Martorana A (2013) Amyloid $\beta$, glutamate, excitotoxicity in Alzheimer's disease: are we on the right track? CNS Neurosci Ther 19:549-555. CrossRef Medline

Fernàndez-Busquets X (2013) Amyloid fibrils in neurodegenerative diseases: villains or heroes? Future Med Chem 5:1903-1906. CrossRef Medline

Grundke-Iqbal I, Iqbal K, Tung YC, Quinlan M, Wisniewski HM, Binder LI (1986) Abnormal phosphorylation of the microtubule-associated protein tau (tau) in Alzheimer cytoskeletal pathology. Proc Natl Acad Sci U S A 83:4913-4917. CrossRef Medline

Guix FX, Uribesalgo I, Coma M, Muñoz FJ (2005) The physiology and pathophysiology of nitric oxide in the brain. Prog Neurobiol 76:126-152. CrossRef Medline

Guix FX, Ill-Raga G, Bravo R, Nakaya T, de Fabritiis G, Coma M, Miscione GP, Villà-Freixa J, Suzuki T, Fernàndez-Busquets X, Valverde MA, de Strooper B, Muñoz FJ (2009) Amyloid-dependent triosephosphate isomerase nitrotyrosination induces glycation and tau fibrillation. Brain 132:1335-1345. CrossRef Medline

Guix FX, Wahle T, Vennekens K, Snellinx A, Chávez-Gutiérrez L, Ill-Raga G, Ramos-Fernandez E, Guardia-Laguarta C, Lleó A, Arimon M, Berezovska O, Muñoz FJ, Dotti CG, De Strooper B (2012) Modification of $\gamma$-secretase by nitrosative stress links neuronal ageing to sporadic Alzheimer's disease. EMBO Mol Med 4:660-673. CrossRef Medline

Hardy J, Selkoe DJ (2002) The amyloid hypothesis of Alzheimer's disease: progress and problems on the road to therapeutics. Science 297:353-356. CrossRef Medline

Hensley K, Carney JM, Mattson MP, Aksenova M, Harris M, Wu JF, Floyd RA, Butterfield DA (1994) A model for beta-amyloid aggregation and neurotoxicity based on free radical generation by the peptide: relevance to Alzheimer disease. Proc Natl Acad Sci U S A 91:3270-3274. CrossRef Medline

Hsia AY, Masliah E, McConlogue L, Yu GQ, Tatsuno G, Hu K, Kholodenko D, Malenka RC, Nicoll RA, Mucke L (1999) Plaque-independent disruption of neural circuits in Alzheimer's disease mouse models. Proc Natl Acad Sci U S A 96:3228-3233. CrossRef Medline

Ill-Raga G, Ramos-Fernández E, Guix FX, Tajes M, Bosch-Morató M, Palomer E, Godoy J, Belmar S, Cerpa W, Simpkins JW, Inestrosa NC, Muñoz FJ (2010) Amyloid- $\beta$ peptide fibrils induce nitro-oxidative stress in neuronal cells. J Alzheimers Dis 22:641-652. CrossRef Medline

Ill-Raga G, Tajes M, Busquets-García A, Ramos-Fernández E, Vargas LM, Bosch-Morató M, Guivernau B, Valls-Comamala V, Eraso-Pichot A, Guix FX, Fandos C, Rosen MD, Rabinowitz MH, Maldonado R, Alvarez AR, Ozaita A, Muñoz FJ (2015) Physiological control of nitric oxide in neuronal BACE1 translation by heme-regulated eIF $2 \alpha$ kinase HRI induces synaptogenesis. Antioxid Redox Signal 22:1295-1307. CrossRef Medline

Klein WL (2002) Abeta toxicity in Alzheimer's disease: globular oligomers (ADDLs) as new vaccine and drug targets. Neurochem Int 41:345-352. CrossRef Medline

Kummer MP, Hermes M, Delekarte A, Hammerschmidt T, Kumar S, Terwel D, Walter J, Pape HC, König S, Roeber S, Jessen F, Klockgether T, Korte M, Heneka MT (2011) Nitration of tyrosine 10 critically enhances amyloid $\beta$ aggregation and plaque formation. Neuron 71:833-844. CrossRef Medline

Li S, Hong S, Shepardson NE, Walsh DM, Shankar GM, Selkoe D (2009) Soluble oligomers of amyloid beta protein facilitate hippocampal longterm depression by disrupting neuronal glutamate uptake. Neuron 62 : 788-801. CrossRef Medline

Lührs T, Ritter C, Adrian M, Riek-Loher D, Bohrmann B, Döbeli H, Schubert 
D, Riek R (2005) 3D structure of Alzheimer's amyloid-beta(1-42) fibrils. Proc Natl Acad Sci U S A 102:17342-17347. CrossRef Medline

Masters CL, Simms G, Weinman NA, Multhaup G, McDonald BL, Beyreuther K (1985) Amyloid plaque core protein in Alzheimer disease and Down syndrome. Proc Natl Acad Sci U S A 82:4245-4249. CrossRef Medline

Meda L, Cassatella MA, Szendrei GI, Otvos L Jr, Baron P, Villalba M, Ferrari D, Rossi F (1995) Activation of microglial cells by beta-amyloid protein and interferon-gamma. Nature 374:647-650. CrossRef Medline

Miranda S, Opazo C, Larrondo LF, Muñoz FJ, Ruiz F, Leighton F, Inestrosa NC (2000) The role of oxidative stress in the toxicity induced by amyloid beta-peptide in Alzheimer's disease. Prog Neurobiol 62:633-648. CrossRef Medline

Murrell J, Farlow M, Ghetti B, Benson MD (1991) A mutation in the amyloid precursor protein associated with hereditary Alzheimer's disease. Science 254:97-99. CrossRef Medline

Perálvarez-Marín A, Barth A, Gräslund A (2008) Time-resolved infrared spectroscopy of $\mathrm{pH}$-induced aggregation of the Alzheimer $\mathrm{A} \beta 1-28$ peptide. J Mol Biol 379:589-596. CrossRef Medline

Petkova AT, Yau WM, Tycko R (2006) Experimental constraints on quaternary structure in Alzheimer's beta-amyloid fibrils. Biochemistry 45:498512. CrossRef Medline

Pierce B, Weng Z (2007) ZRANK: reranking protein docking predictions with an optimized energy function. Proteins 67:1078-1086. CrossRef Medline

Ramos-Fernández E, Tajes M, Palomer E, Ill-Raga G, Bosch-Morató M, Guivernau B, Román-Dégano I, Eraso-Pichot A, Alcolea D, Fortea J, Nuñez L, Paez A, Alameda F, Fernández-Busquets X, Lleó A, Elosúa R, Boada M, Valverde MA, Muñoz FJ (2014) Posttranslational nitro-glycative modifications of albumin in Alzheimer's disease: implications in cytotoxicity and amyloid- $\beta$ peptide aggregation. J Alzheimers Dis 40:643-657. CrossRef Medline

Reed TT, Pierce WM Jr, Turner DM, Markesbery WR, Butterfield DA (2009) Proteomic identification of nitrated brain proteins in early Alzheimer's disease inferior parietal lobule. J Cell Mol Med 13:2019-2029. CrossRef Medline

Rezaei-Ghaleh N, Amininasab M, Giller K, Kumar S, Stündl A, Schneider A, Becker S, Walter J, Zweckstetter M (2014) Turn plasticity distinguishes different modes of amyloid- $\beta$ aggregation. J Am Chem Soc 136:49134919. CrossRef Medline

Rossi F, Bianchini E (1996) Synergistic induction of nitric oxide by betaamyloid and cytokines in astrocytes. Biochem Biophys Res Commun 225: 474-478. CrossRef Medline

Schindelin J, Arganda-Carreras I, Frise E, Kaynig V, Longair M, Pietzsch T, Preibisch S, Rueden C, Saalfeld S, Schmid B, Tinevez JY, White DJ, Hartenstein V, Eliceiri K, Tomancak P, Cardona A (2012) Fiji: an opensource platform for biological-image analysis. Nat Methods 9:676-682. CrossRef Medline

Schneider CA, Rasband WS, Eliceiri KW (2012) NIH Image to ImageJ: 25 years of image analysis. Nat Methods 9:671-675. CrossRef Medline

Selkoe DJ (2002) Alzheimer's disease is a synaptic failure. Science 298:789791. CrossRef Medline

Selkoe DJ (2008) Soluble oligomers of the amyloid beta-protein impair syn- aptic plasticity and behavior. Behav Brain Res 192:106-113. CrossRef Medline

Serpel LC (2000) Alzheimer's amyloid fibrils: structure and assembly. BBA Mol Basis Dis 1502:16-30. CrossRef Medline

Shankar GM, Li S, Mehta TH, Garcia-Munoz A, Shepardson NE, Smith I, Brett FM, Farrell MA, Rowan MJ, Lemere CA, Regan CM, Walsh DM, Sabatini BL, Selkoe DJ (2008) Amyloid-beta protein dimers isolated directly from Alzheimer's brains impair synaptic plasticity and memory. Nat Med 14:837-842. CrossRef Medline

Smith MA, Richey Harris PL, Sayre LM, Beckman JS, Perry G (1997) Widespread peroxynitrite-mediated damage in Alzheimer's disease. J Neurosci 17:2653-2657. Medline

Szabó C, Ischiropoulos H, Radi R (2007) Peroxynitrite: biochemistry, pathophysiology and development of therapeutics. Nat Rev Drug Discov 6:662-680. CrossRef Medline

Tajes M, Guivernau B, Ramos-Fernández E, Bosch-Morató M, Palomer E, Guix FX, Muñoz FJ (2013) The pathophysiology of triose phosphate isomerase dysfunction in Alzheimer's disease. Histol Histopathol 28:4351. Medline

Tajes M, Eraso-Pichot A, Rubio-Moscardó F, Guivernau B, RamosFernández E, Bosch-Morató M, Guix FX, Clarimón J, Miscione GP, Boada M, Gil-Gómez G, Suzuki T, Molina H, Villà-Freixa J, Vicente R, Muñoz FJ (2014) Methylglyoxal produced by amyloid- $\beta$ peptideinduced nitrotyrosination of triosephosphate isomerase triggers neuronal death in Alzheimer's disease. J Alzheimers Dis 41:273-288. CrossRef Medline

Tamagno E, Bardini P, Obbili A, Vitali A, Borghi R, Zaccheo D, Pronzato MA, Danni O, Smith MA, Perry G, Tabaton M (2002) Oxidative stress increases expression and activity of BACE in NT2 neurons. Neurobiol Dis 10:279-288. CrossRef Medline

Vassar R, Bennett BD, Babu-Khan S, Kahn S, Mendiaz EA, Denis P, Teplow DB, Ross S, Amarante P, Loeloff R, Luo Y, Fisher S, Fuller J, Edenson S, Lile J, Jarosinski MA, Biere AL, Curran E, Burgess T, Louis JC, et al. (1999) Beta-secretase cleavage of Alzheimer's amyloid precursor protein by the transmembrane aspartic protease BACE. Science 286:735-741. CrossRef Medline

Wahlström A, Hugonin L, Perálvarez-Marín A, Jarvet J, Gräslund A (2008) Secondary structure conversions of Alzheimer's $A \beta(1-40)$ peptide induced by membrane-mimicking detergents. FEBS J 275:5117-5128. CrossRef Medline

Webb B, Sali A (2014) Protein structure modeling with MODELLER. Methods Mol Biol 1137:1-15. CrossRef Medline

Xia W, Zhang J, Ostaszewski BL, Kimberly WT, Seubert P, Koo EH, Shen J, Selkoe DJ (1998) Presenilin 1 regulates the processing of beta-amyloid precursor protein C-terminal fragments and the generation of amyloid beta-protein in endoplasmic reticulum and Golgi. Biochemistry 37: 16465-16471. CrossRef Medline

Zhang R, Hu X, Khant H, Ludtke SJ, Chiu W, Schmid MF, Frieden C, Lee JM (2009) Interprotofilament interactions between Alzheimer's Abeta 1-42 peptides in amyloid fibrils revealed by cryoEM. Proc Natl Acad Sci U S A 106:4653-4658. CrossRef Medline

Zhao J, Wang P, Li H, Gao Z (2015) Nitration of Y10 in A $\beta$ 1-40: is it a compensatory reaction against oxidative/nitrative stress and $\mathrm{A} \beta$ aggregation? Chem Res Toxicol 28:401-407. CrossRef Medline 